\title{
Role of Maternal Microbiota and Nutrition in Early-Life Neurodevelopmental Disorders
}

\author{
Anissa Daliry *(D) and Evelyn Nunes Goulart da Silva Pereira \\ Laboratory of Cardiovascular Investigation, Oswaldo Cruz Institute, Oswaldo Cruz Foundation, \\ Rio de Janeiro 21040-900, Brazil; evyspereira@gmail.com \\ * Correspondence: daliry@ioc.fiocruz.br; Tel.: +55-212562-1312
}

\begin{abstract}
The rise in the prevalence of obesity and other related metabolic diseases has been paralleled by an increase in the frequency of neurodevelopmental problems, which has raised the likelihood of a link between these two phenomena. In this scenario, maternal microbiota is a possible linking mechanistic pathway. According to the "Developmental Origins of Health and Disease" paradigm, environmental exposures (in utero and early life) can permanently alter the body's structure, physiology, and metabolism, increasing illness risk and/or speeding up disease progression in offspring, adults, and even generations. Nutritional exposure during early developmental stages may induce susceptibility to the later development of human diseases via interactions in the microbiome, including alterations in brain function and behavior of offspring, as explained by the gut-brain axis theory. This review provides an overview of the implications of maternal nutrition on neurodevelopmental disorders and the establishment and maturation of gut microbiota in the offspring.
\end{abstract}

Keywords: gut microbiota; neurodevelopmental disorders; obesity; gut-brain axis; maternal diet

Citation: Daliry, A.; Pereira,

E.N.G.d.S. Role of Maternal

Microbiota and Nutrition in

Early-Life Neurodevelopmental

Disorders. Nutrients 2021, 13, 3533.

https://doi.org/10.3390/nu13103533

Academic Editors:

Vicente Andreu-Fernández

and Giorgia Sebastiani

Received: 8 July 2021

Accepted: 24 August 2021

Published: 9 October 2021

Publisher's Note: MDPI stays neutral with regard to jurisdictional claims in published maps and institutional affiliations.

Copyright: (c) 2021 by the authors. Licensee MDPI, Basel, Switzerland. This article is an open access article distributed under the terms and conditions of the Creative Commons Attribution (CC BY) license (https:// creativecommons.org/licenses/by/ $4.0 /)$.

\section{Introduction}

Over the last 50 years, the prevalence of adult and childhood obesity has increased worldwide, reaching pandemic proportions [1]. Overweight and obesity affect over 1.9 billion adults, with 650 million of them being obese [2]. Obesity, which is the main risk factor for cardiovascular diseases, cancer, diabetes mellitus, and non-alcoholic fatty liver disease (NAFLD), accounts for more than $70 \%$ of early deaths worldwide and is the leading cause of mortality and premature disability [3].

The increase in the prevalence of obesity and other related metabolic diseases has been paralleled by an increase in neurological problems, both in adults and in children [4-7]. Epidemiologic studies have found a link between maternal metabolic diseases and offspring's neurodevelopmental and psychiatric morbidity, including intellectual disability, cognitive impairment, autism spectrum disorders (ASD), and attention deficit hyperactivity disorder (ADHD). Obesity in mothers is linked to a 3.6-fold greater risk of intellectual disability or cognitive impairment in their children [8-11]. In addition, a positive association between high maternal body mass index (BMI) and ASD in offspring is widely observed (odds ratio range from 1.5 to 1.7) [12-15]. This risk is increased by preterm birth [14], high gestational weight gain [15], gestational or pre-gestational diabetes [12,13] and preeclampsia [16]. Large cohort studies have shown that ADHD symptoms in offspring increase in a dose-dependent manner accordingly to maternal pre-pregnancy BMI increase, from overweight to obese [17]. Other studies have reported a 1.6- to 2.8-fold greater risk of ADHD in offspring of obese mothers [18-20].

The exact etiology underlying neurodevelopmental disorders remains a challenge, but several genetic and nongenetic (exposome) factors are known to interact early in life to influence the risk for developing neurological diseases [21]. During pregnancy and early life, several environmental factors could influence the risk for developing neurodevelopmental disorders, including dietary pattern (healthy or unhealthy), socioeconomic 
aspects, infectious diseases, stress, pollutants, mode of delivery (vaginal or cesarean), and feeding pattern (breastfeeding or artificial feeding) [22]. In this scenario, a mechanistic knowledge of how the intrauterine environment of the mother and lactation may regulate offspring neurodevelopment is critical in exploring a causal relationship between these two phenomena. A potential mechanistic pathway linking maternal nutrition and offspring outcomes is the transmission of maternal microbiota. The human gut microbiota is made up of a complex and dynamic population of more than 10 trillion species, including bacteria, archaea, yeasts, and protozoa [23].

The gut microbiota acts as a metabolic organ, performing tasks not encoded in the human genome, such as producing metabolites not created by the human body [24] and delivering critical nutrients by degrading otherwise indigestible polysaccharides and sugars $[25,26]$. Furthermore, the gut microbiota has a role in the development, maturity, and maintenance of critical human systems such as the immune system [27], gastrointestinal tract function [26], and metabolism [28,29].

The concept of the gut-brain axis specifies a bidirectional signaling pathway between the gastrointestinal system and the central nervous system, linked by neurons of the sympathetic and parasympathetic nervous systems, as well as by circulating hormones and other neuromodulators [30]. Dysfunction of the gut-brain axis has been visualized as an essential mediator in the pathogenesis of neurodegenerative diseases [30-32].

As the microbiota is shared between the mother and child, maternal diet can influence the microbiota of the offspring. In the gastrointestinal system, a complex combination of mother and offspring factors generates a unique microbiome [33]. The concept of fetal microbiome, which postulates that microbial colonization begins in utero, remains controversial [34-37]; however, a wealth of evidence demonstrates that the microbiota of the mother can be seeded in the offspring at the time of birth via vertical transmission from the reproductive and gastrointestinal tracts [38-42] and can be transmitted by breastfeeding [43].

Therefore, promoting a balanced and diverse composition of the maternal gut microbiota is critical for establishing the first life bacterial community required to line the offspring on a healthy developmental trajectory. This review provides an overview of the complex network between diet-induced changes in intestinal microbiota and its possible links with neurodevelopmental disorders of the offspring. In this regard, we shed light on the dietary factors that affect the maternal and offspring microbiota and the pathways by which these changes affect the neurodevelopmental outcomes of the offspring.

\section{Maternal Obesity and Child Neurodevelopmental Disorders}

A recent meta-analysis showed that mothers who were overweight or obese before pregnancy had $17 \%$ and $51 \%$ higher chance, respectively, of having a child with poor neurodevelopmental outcomes. Children born to overweight/obese women had a higher incidence of ADHD (62\%), cognitive or intellectual delay (58\%), emotional or behavioral problems (42\%), and ASD (36\%) [44]. Ornoy and colleagues showed that school-age children born to mothers with diabetes or gestational diabetes exhibited neurobehavioral and motor disorders, mostly inattention and fine and gross motor impairment [45]. Studies have shown that the combined effect of maternal obesity and diabetes has more pronounced effects on the risk of ASD in children than the isolated effect of each condition [13,46].

The average score of children aged 6 to 9 years on the Bruininks-Oseretsky Test of Motor Proficiency correlated significantly with the level of maternal $\beta$-hydroxybutyrate (BHA) ketone bodies, suggesting prenatal and perinatal impacts on long-term neurodevelopmental course of diabetic mothers' offspring [47].

Maternal elevated BMI is a risk factor for ADHD, but some authors suggest that it may not be a potential causal effect, as sibling comparisons showed significant attenuation of the previously observed associations, indicating that the association of maternal elevated BMI could at least, in part, be attributed to familial confounding factors $[19,48]$. 
Overweight and obese women have an increased risk of preterm birth ( $<37$ weeks), which is a risk factor for neurodevelopmental disorders [49]. Preterm-born children evaluated at school age showed more than two-fold increased relative risk of developing ADHD and reduced cognitive test scores $[50,51]$. The mean cognitive scores at school age were directly proportional to the severity of prematurity at birth. The lower scores for motor, cognitive, and academic tests of preterm children at preschool age persisted in the primary school years [51]. Likewise, children of obese mothers with high birth weight $(\geq 3.6 \mathrm{~kg})$ had an increased risk of attention problems [52].

Though the mechanisms that account for the development of brain dysfunction in the offspring of mothers with metabolic diseases are not fully understood, the metabolic capacities of the gut microbiota and the crosstalk with the developing brain during early life may play a pivotal role in this process (Figure 1).

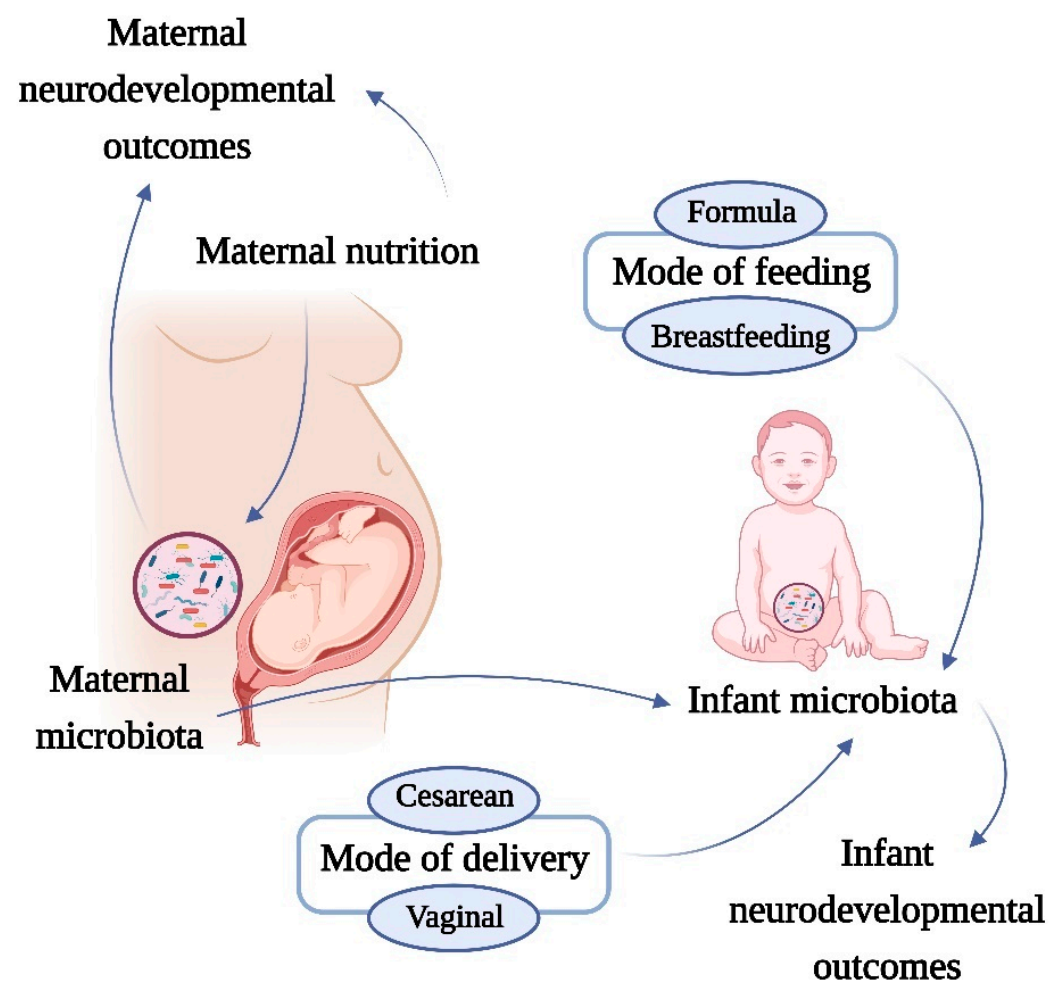

Figure 1. Effects of maternal microbiota and nutrition on neurodevelopmental disorders. The increase in prevalence of nutrition-related metabolic diseases has been paralleled by an increase in neurological problems, both in adults and in children. A possible mechanistic pathway linking nutrition and neurodevelopmental outcomes is the microbiota. Several factors can affect the neonatal microbiome. The microbiota is shared between mother and child, therefore the maternal diet, mode of feeding and mode of delivery can influence the microbiota of the offspring. This complex network involving earlylife microbiota development can induce changes that link with the neurodevelopmental disorders of the infant.

\section{The Effect of Maternal Diet on the Offspring Microbiota}

Microbiota modifications induced by recent changes in the human environment, such as the amount and composition of the diet, appear to be a key determinant of child health [53-57] (Figure 2). In fact, the link between food and health has been proposed since antiquity and can be exemplified by the concept of "let the food be thy medicine and medicine be thy food" postulated by the Greek physician Hippocrates, 2000 years ago. We now understand that nutrients can directly interact with microorganisms to boost or decrease their growth kinetics and to modulate their ability to extract energy from specific dietary elements, giving chosen members of the gut microbial community a direct competitive advantage [58] (Figure 2). 


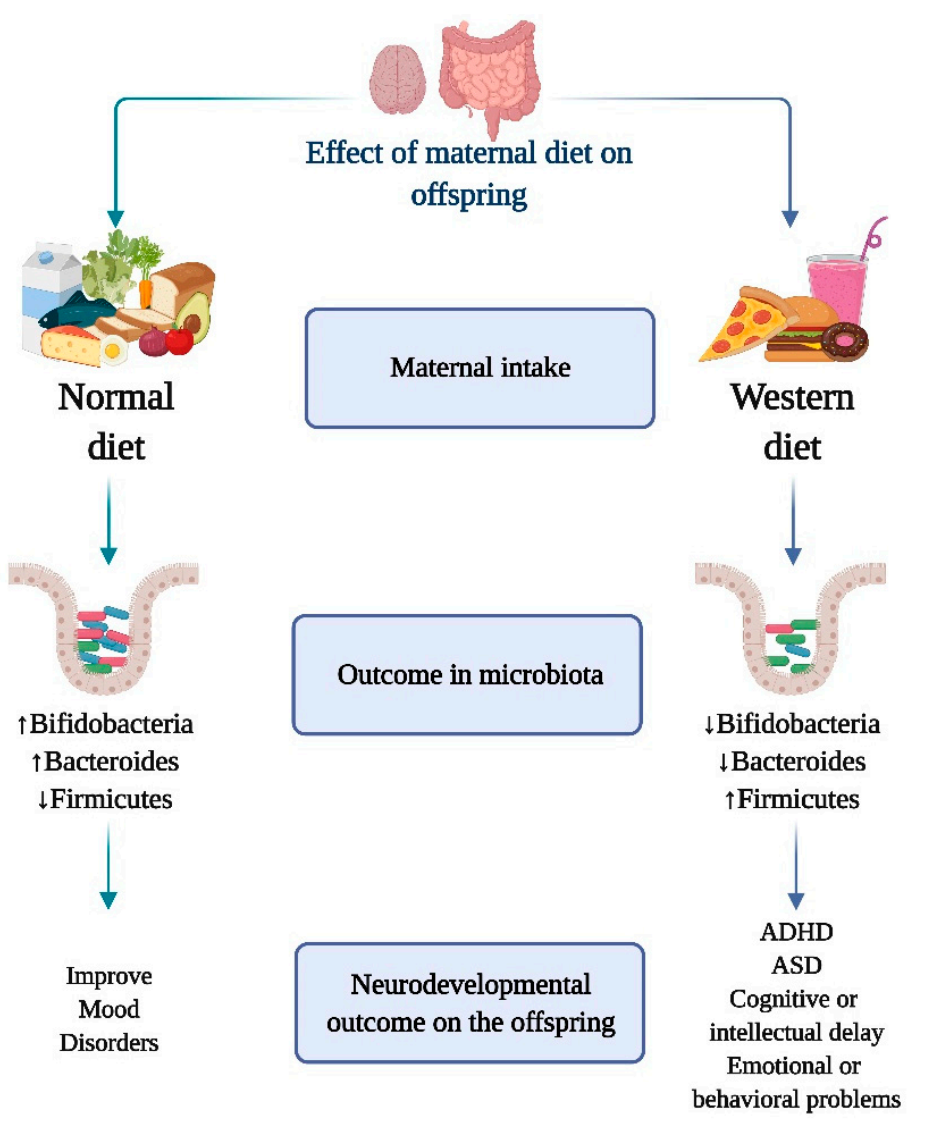

Figure 2. Role of maternal diet on the interaction of gut microbiota and neurodevelopmental outcome on the offspring. Increase in Bifidobacteria and Bacterioids and decrease in Firmicutes, is associated with the consumption of a healthy and nutritionally balanced maternal diet. This "healthy" dietary and microbiome profile has been linked to the prevention of neurodevelopmental problems and the onset of mental disorders. On the other hand, maternal intake of a diet rich in sugars, lipids and low in fruits and vegetables (Western diet) is associated with a decreased population of Bifidobacteria and Bacterioids increased Firmicutes species. The onset of neurodevelopmental illnesses such as attention deficit hyperactivity disorder (ADHD), autism spectrum disorder (ASD), cognitive or intellectual delay, and emotional or behavioral problems has been linked to the Western diet and its distinctive microbiome composition.

Importantly, changes in the mother's diet prior to and during pregnancy can modify the infant gut microbiota [59-61]. According to the "Developmental Origins of Health and Disease" paradigm, environmental exposures (in utero and during early life) can permanently modify the body's structure, physiology, and metabolism, resulting in higher risk and/or acceleration of disease in adulthood and across generations [62,63]. From an evolutionary perspective, maternal transfer of excess nutrients may have contributed to better offspring survival chances; however, nowadays, one of the most powerful predictors of childhood obesity is exposure to a scenario of gut dysbiosis of maternal origin, such as obesity and diabetes mellitus [64].

Cohort studies have demonstrated that imbalanced nutrition arising from excessive intake of nutrients during pregnancy increases the progeny's vulnerability to metabolic disorders [65-69]. Microbial dysbiosis arising from a maternal high-fat diet was linked to a neuroinflammatory profile in the offspring's hippocampus and amygdala, resulting in reduced social behavior and an anxiety-like phenotype in non-human primates and rodents [70]. Molecules that can cross the maternal compartment represent a risk to developmental programming in offspring, and an inadequate intake of macro-and micronutrients during pregnancy has been linked to an altered maternal microbiome [71] and poor neurocognition in offspring [72]. As a result, mother weight status, whether 
pre-pregnancy weight or excess gestational weight gain, may have major implications on neurodevelopmental outcomes in the offspring.

The Western diet is characterized by a high content of refined sugar, omega- 6 polyunsaturated fats, and fast food, with an associated reduced consumption of fruits, vegetables, and fibers [73]. Several studies have explored maternal overweight- or obesity-associated changes in the microbiome of the early-life gut, and the consumption of high-fat diets is a common cause of macronutrient consumption imbalance during pregnancy (Figure 2). The maternal and offspring microbiota in humans and rodents are influenced by the type of diet consumed prior to or during pregnancy [74-76]. Fecal Bacteroides and Staphylococcus concentrations increase during the first 6 months of life in infants born to overweight mothers, while bifidobacterial concentrations are higher in infants from lean mothers [76]. Studies in Yucatan pigs revealed that a maternal Western diet during pregnancy and lactation, even in the absence of obesity, can modify the microbiota of the offspring and have significant consequences on blood lipid levels, gut-brain axis, and neurocognitive skills after weaning [77]. Maternal exposure to a Western diet generated alterations in the intestinal microbiota composition of the offspring in suckling mouse pups, including a higher Firmicutes/Bacteroidetes ratio and a significant decrease in relative abundance of Akkermansia, a Verrucomicrobiaceae member, which lives in the outer mucus layer of the colon and has been proposed as "healthy" intestine marker [74].

Mechanistically, a high-fat diet prior to and during pregnancy has been shown to impair maternal hypothalamic-pituitary-adrenal axis plasticity and hypothalamic gene response to stress in the offspring $[78,79]$. The offspring of mothers exposed to a Western diet showed significant changes in the expression of crucial genes responsible for normal functioning of the intestine, including cholecystokinin hormones, ATP-binding cassette transporter A1, fructose transporter GLUT5, and immune response/inflammation-related genes such as Ly86, Cxcr6, and CD74, indicating that mothers' food choices are critical for the proper development of the intestine in their offspring [74]. Together, these findings support the importance of counseling pregnant mothers about their nutritional needs during pregnancy and lactation, and emphasize the importance of diet-induced gut microbiota modulation (Figure 2).

\section{Early-Life Microbiota Colonization}

\subsection{Birth Mode}

Cesarean section rates have exponentially increased around the world in recent years and at present, it exceeds the World Health Organization (WHO) recommendations [80]. This may lead to several implications, as the mode of delivery may affect the early life microbiota, leaving a lasting imprint on the biology of offspring [81]. The mother cervicovaginal and fecal microbes dominate the microbial inoculum of vaginally delivered neonates, whereas cesarean birth imparts unique microbial consortia and are frequently dominated by skin microorganisms [40-42].

Many studies have revealed correlations between birth mode and neurodevelopmental disorders in the offspring. Cesarean delivery has been linked to an increased risk of neurodevelopmental and psychiatric outcomes, including ASD (33\% increased odds) and ADHD (17\% increased odds), intellectual disabilities, obsessive compulsive disorder, tic disorders, and eating disorders [82,83]. However, causality has not yet been confirmed, as confounding factors should be taken into account, including familial factors [84-88], and that emergency C-Section is often the result of pregnancy (e.g., preeclampsia and gestational diabetes) and/or birth (e.g., fetal distress, dystocia, and failed induction) complications, which could also affect brain development. In addition, there is a potential genetic overlap between psychiatric disorders and the likelihood of delivery by C-section [89,90].

In the first months of life, bifidobacteria are more abundant in children exposed to microbes via vaginal delivery than in children born via cesarean delivery, who have more Enterococcus spp. and Klebsiella spp. [81,91,92]. The modulation of host defensive responses is a unique benefit of bifidobacteria; acetate produced in large amounts by preventative 
bifidobacteria exerts action on the colonic epithelium by generating anti-inflammatory and anti-apoptotic effects [93]. In contrast, cesarean delivery is associated with a higher population of potentially pathogenic microorganisms, which are commonly associated with the skin, oral cavity, and hospital environment [40,94], and increased levels of proinflammatory markers, which are linked to the offspring's development of depression, learning, and memory deficits $[82,95,96]$.

Reduced levels of intestinal Bacteroides spp., associated with C-section delivery, have significant influence on human physiology and metabolism. Alterations in gut microbiota of offspring by synergic birth factors also increases the risk of developing metabolic diseases such as obesity and type 1 diabetes $[97,98]$. A preclinical study demonstrated that mice delivered by C-section exhibited social, cognitive, and anxiety problems in early life, and the Bifidobacterium breve strain supplementation was able to reverse these selective behavioral alterations [99]. A cross-sectional study of 8900 preschool children found that the odds of being overweight and obese were 1.35 and 1.25, respectively, in children delivered by C-section [100]. In a cohort study of 935 overweight and obese mothers, both vaginally and cesarean-delivered offspring had three and five times more risk, respectively, to become overweight at ages 1 and 3 years, respectively, compared with offspring born vaginally to a mother of normal weight. Although several other factors may influence childhood obesity, such as genetic components [101] and psychological and psychiatric components that may affect maternal and child feeding habits [102,103], it is intriguing that the likelihood of being obese, in children born to obese mother, is higher in children delivered by C-section than in children delivered vaginally, suggesting that the risk of childhood obesity may depend on the mode of delivery. A higher Firmicutes species richness was observed in the microbiota of children of overweight mothers; however, the participating genera of Lachnospiraceae differed between vaginal and cesarean deliveries. Therefore, the birth mode and infant gut microbiota in the offspring gut may act as sequential mediators of the association between maternal pre-pregnancy and pregnancy metabolic status and child overweight and/or neurodevelopmental disorders [42].

These findings suggest that birth mode alters intestinal microbiota, leading to various metabolic consequences, including obesity and metabolic dysfunction. Furthermore, C-section may disturb the maturation of the microbiota-brain-gut axis, altering developmental trajectories and perhaps leading to the emergence of neurodevelopmental and other brain diseases later in life [32,104-108] (Figure 1).

\subsection{Infant Feeding Mode}

Breastfeeding is recommended by the World Health Organization (WHO) and the American Academy of Pediatrics (AAP) as the best source of nourishment for newborns throughout the first six to twelve months of life $[109,110]$. Breastfeeding has been proven in several studies to provide short- and long-term benefits, including protection against cognitive development, ADHD, and ASD [111]. Breastfeeding has also been studied for its emotional benefits, which have been linked to increased oxytocin levels [112] and improved mother-infant bonding $[113,114]$, both of which promote greater maternal sensitivity and responsiveness [115], which has independent effects on maternal caregiving and infant brain development.

Feeding type (whether breastfed or formula fed) is another major factor that affects the development and complexity of the microbiota [116] (Figure 1). Studies have shown that human milk is not sterile and that maternal microbiota and other factors in breastmilk are a continuous source of colonizing microbes to the offspring's gut, modulating microbiota composition and immunological function in offspring, and can influence neural development [117].

Breastfeeding is the dietary element that is most consistently associated with gut microbial diversity in offspring when compared to formula feeding [118]. Formula-fed newborns, on the other hand, show a decline in bacterial variety and richness even after the first year of life [41]. The presence of the same bacterial strain in breast milk and 
the feces of breastfed infants indicated the mother-to-child microbiota transmission [119]. Martín et al., in a study with 10 mother-infant pairs, showed that the genera that were found in both infant feces and human milk samples accounted for $70-88 \%$ of the overall relative abundance in infant feces samples, confirming the notion of vertical bacterial transmission from milk to the infant gut. In addition, Bifidobacterium breve and Lactobacillus plantarum bacteria with identical characteristics were recovered from milk and infant feces samples [120].

Viable skin and non-skin Gram-positive bacteria are present in the breast milk. Streptococci of the mitis and salivarius groups, as well as coagulase negative staphylococci, predominate both in human milk and feces of breastfed newborns [92,121-124]. These microorganisms, which are less common in formula-fed newborns, may be able to prevent the establishment of undesired pathogens in the infant gut [125-127]. Bacteroides and Bifidobacterium have a higher relative abundance in the gut bacterial population of exclusively breastfed infants [128]. A large longitudinal study involving 903 children aged 3 to 46 months showed that breastfeeding was linked to greater levels of Bifidobacterium species (B. breve and B. bifidum). The discontinuation of breastfeeding led to alteration of the microbiome, resulting in a rapid maturation of the gut microbiome, as indicated by the increase in species of the phylum Firmicutes [129].

Human milk is also rich in nutrients, among which oligosaccharides are the third most abundant after lactose and lipids. Human milk oligosaccharides can act as prebiotics, triggering the growth of particular bacterial groups, such as Bifidobacterium, with more than a two-fold increase in the number of bacteria compared to the microbiota of formulafed infants [130].

Maternal obesity may influence offspring microbiota and neurodevelopmental disorders through different mechanisms. Maternal obesity can result in the prevalence of pro-inflammatory fatty acids in breast milk beyond those levels critical for offspring neurodevelopment. Compared to breastmilk from lean mothers, breastmilk from obese mothers had a higher omega- 6 to omega- 3 fatty acid ratio and lower concentrations of eicosapentaenoic, docosahexaenoic and docasapentaenoic acids, and lutein, which together induces a pro-inflammatory state and decreases neuroprotective properties [131]. Higher concentrations of fatty acids, such as docosahexaenoic acid, have been linked to improved visual and language development [132].

Considering the breastfeeding-gut-brain axis mechanism, both breast milk microorganisms and prebiotics play critical role in the development of the microbiome in the offspring, leading to neurodevelopment- associated outcomes. In a preclinical study, Tarr et al. demonstrated that milk oligosaccharides sustain normal microbial population and behavioral responses following stressor exposure, possibly through effects on the gut microbiota-brain axis, and maintain normal behavior on tests of anxiety-like behavior and normal numbers of doublecortin-positive immature neurons [133].

Although the mechanisms behind breastfeeding-induced beneficial effects are not fully explained, it is possible that the standard microbial environment provided by breast milk versus formula feeding may play a key role in offspring neural development. Therefore, the mother's commitment to a healthy and balanced diet, associated with breastfeeding, will have significant positive impacts on infant microbiome, and prevent the onset of neurodevelopmental problems.

\section{Microbiota as a Metabolic Factory}

The microbiota can be viewed as an active "organ" with metabolic capacities that we did not have to develop on our own. These functions include the ability to handle indigestible food components such as plant polysaccharides, synthesize vitamin $\mathrm{K}$ and other vitamins belonging to the B complex, supplying essential components [134,135]. Gut microbes metabolize polysaccharides and complex carbohydrates to short-chain fatty acids (SCFAs), such as butyrate, acetate, and propionate [136], which can be used as energy sources by other organs and cells. Colonocytes use butyrate as their principal 
energy source, while propionate and acetate are utilized by the liver for lipogenesis and gluconeogenesis [137,138].

Seminal studies have shown that germ-free (GF) animals have lower total fat content than conventionalized or fecal-transplanted animals [134], suggesting that microbiota can affect host fat storage and energy metabolism [134]. Microbiotas participate in host fat storage by increasing dietary polysaccharide processing, and elevating key enzymes and proteins involved in de novo hepatic lipogenesis, such as acetyl-CoA carboxylase (Acc1), fatty acid synthase (Fas), sterol response element binding protein 1 (SREBP-1), and carbohydrate response element binding protein (ChREBP). As a result, higher triglyceride content in the liver and increased fat storage in adipocytes promote the storage of calories obtained from the diet into fat $[134,139]$.

While more than $90 \%$ of bacteria comprising the mouse and human distal gut microbiota are members of the Bacteroidetes and Firmicutes phyla [140-143], obesity is linked to a higher relative abundance of Firmicutes and a lower relative abundance of Bacteroidetes $[140,141]$. Furthermore, when a lean diet is substituted, obese people lose weight and restore Bacteroidetes $[69,140,144]$. Studies on $o b / o b$ mice, diet-induced obese mice, and humans have demonstrated the presence of an obesity-associated gut microbiota with higher ability for energy harvesting from the food $[69,144]$. Western diet-fed mice were enriched for the Mollicute lineage Eubacterium dolichum within the Firmicutes phylum, which reached an average of $70 \%$ of the gut microbiome [144]. The colonization of GF mice with microbes from an obese donor, resulted in significantly greater adiposity, providing the first evidence that differences in the murine gut microbiome are sufficient to alter host body composition [69].

Questions remain to be answered on the mechanisms that mediate the association between the relative abundance of Bacteroidetes to Firmicutes divisions and obesity, and to what extent this relationship can self-perpetuate. Changes in the population dynamics, interactions, and distributions of microbiota caused by obesity may act as an "environmental" factor that leads to a predisposition toward higher energy harvest from the diet and increased storage in tissues. This obesity-related microbiome may contribute to increased infant adiposity, which may lead to elevated inflammatory state and neurotoxicity, and thus contribute to a compromised neurodevelopment [145-152].

\section{Important Bioactive Nutrients and Their Association with the Gut Microbiota}

\subsection{Micronutrients}

Deficiencies in micronutrients are a global health challenge, and the gut microbiome is malleable and varies significantly due to micronutrient composition. Micronutrients are critically important for cellular development and differentiation, metabolism, immune system function, and neurological development during fetal, newborn and infant growth.

Preclinical studies with GF animals demonstrated that the gut microbiota plays a role in iron uptake and storage [153,154]. Hibberd MC et al. [155] showed that vitamin A deficiency has a huge effect on gut microbial community, causing an abundance increase in Bacteroides vulgatus. Studies in rodents and humans have demonstrated impairments in neurocognitive development due to deficiencies in micronutrients including zinc [156-160], iron [161-164], and B vitamins [165-168]. A study analyzing the oral, gut, vaginal, and breast milk microbiotas in pregnant women provided with a daily micronutrient-supplemented probiotic yogurt reported an increase in the relative abundance of Bifidobacterium and a decrease in Enterobacteriaceae in the feces of newborn [169]. Glycans in milk promote bifidobacterial growth, and specific milk oligosaccharides increase following micronutrient/probiotic supplemented induced by yogurt consumption [169]. Folate, the natural form of vitamin B9, is an essential cofactor in a variety of biological pathways, including nucleotide biosynthesis and DNA methylation [170]. Folate deficiency during pregnancy has been associated with increased neural tube defects, such as spina bifida, in offspring [171]. Besides dietary sources, intestinal bacteria in the colon can produce substantial amounts of folate as well as other B-vitamins [172]. In fact, 
more than $18 \%$ of the folate requirement can be fulfilled by bacterial folate biosynthesis [173]. The identification of a proton-coupled, high-affinity folate transporter in the human colon implies that bacterially biosynthesized folate can be absorbed and participate in host metabolism [174]. Folate deficiency has been associated with sensory axonal neuropathy $[175,176]$ and psychiatric features, including cognitive decline, cognitive deficits, depression, and schizophrenia [177-179]. In rats with Alzheimer's disease-like dementia, folate and vitamin B12 deficiencies additively impaired memory function by blunting hippocampal insulin signaling and modifying the gut microbiota [180].

Magnesium $(\mathrm{Mg})$ modulates neuronal transmission and neuromuscular coordination in the brain, is a cofactor for a variety of enzymes, as well as participates in RNA, DNA, and protein stability $[181,182]$. Mg protects against excitotoxicity and neuronal cell death by blocking the calcium channel in the N-methyl-D-aspartate (NMDA) receptor [181,183-185]. Brain Mg concentration enhances synaptic plasticity which affects learning and memory skills $[186,187]$. Magnesium $(\mathrm{Mg})$ deficiency is linked to an inflammatory and oxidative state characterized by increased in IL- 6 and TNF- $\alpha$, while Mg supplementation induces changes in microbiota that are associated with protective effects [188]. The content of bifidobacteria, and to a lesser extent of lactobacilli, decreases in the cecum during short-term $\mathrm{Mg}$ deficiency, independent of any significant change in other nutrient intake [188]. In a clinical study, Effatpanah et al. showed that subjects with ADHD had lower serum Mg levels compared with healthy controls [189].

Zinc is a structural component of many proteins and a cofactor of over 300 enzymes that regulate a variety of cellular functions and cellular signaling pathways important for brain and body health [190]. Zinc is also found in synaptic vesicles in the brain, especially in glutamatergic terminals [191-193]. Moreover, Zinc is involved in neuronal activity and affects the activity of N-methyl-D-aspartate (NMDA), $\alpha$-amino-3-hydroxyl-5-methyl-4isoxazole-propionate (AMPA), GABAA, glycine inotropic [194] and GPR39 receptors [195]. In physiological concentrations, Zinc has neuroprotective properties but is neurotoxic in excessive amounts [196-199]. As a result, an imbalance in zinc homeostasis has harmful effects on a range of brain processes, eventually leading to the neurodevelopmental disorders and psychiatric diseases [200]. Evidence from animal models has shown that the gut microbiome is able to collect zinc from the host cells when this element is scarce, which in turn influences the host-microbiota composition, leading to inflammation of the intestinal wall [201]. Zinc deficiency in pregnant mice has been associated with abnormal gut-brain signaling by altering gut physiology, being linked to microbiota dysbiosis and triggering an increase in inflammatory markers such as IL-6, IL-1 $\beta$, and CCL2 [202]. Zinc supplementation combined with treatment effectively improved the symptoms of the attention-deficit disorder subtype of ADHD in 150 children aged 6 to 15 years in a randomized, double-blind clinical trial [203].

The vitamin D receptor (VDR), vitamin D metabolites, and enzymes important for vitamin D activation have been detected in the brain and central nervous system [204] suggesting that vitamin $\mathrm{D}$ is associated with cognitive function. Experiments have also shown that active vitamin D influences brain and neuron development [205] and has neuroprotective and antioxidant properties [204]. In addition, vitamin D deficiency has been associated with ageing, behavioral, social, motor, and sensory deficits [206-209]. Moreover, in humans, vitamin D has been shown to modulate host immune responses against certain bacteria and affect the composition of the gut microbiota. Multiple sclerosis, autism, and Alzheimer's disease, among other neuroinflammatory illnesses, characterized by potential microbiome abnormalities, have been linked to vitamin D deficiency [210-212]. In a metaanalysis, Shen and Ji reported that subjects deficient in vitamin D were at an increased risk of developing Alzheimer's disease [210]. Mostafa and Al-Ayadhi determined that children with autism had significantly lower vitamin D serum levels than healthy children [213]. Evidence supports the critical role of vitamin D in the maintenance of gastrointestinal homeostasis, microbiota composition, and regulation of mucosal inflammatory responses [214]. Vitamin D also has proven effects on the modulation of pattern recognition receptors [215] 
and maintenance of the intestinal barrier function [216,217]. Increased serum vitamin D was associated with a decreased Firmicutes to Bacteroidetes ratio, increasing beneficial bacteria, and decreasing pathogenic bacteria [218]. Mechanistically, vitamin D deficiency is associated with increased expression of Paneth cell defensins, tight junction genes and mucin-2, and decreased levels of circulatory lipopolysaccharide [219]. In addition, the gut microbiota and vitamin D deficiency in prenatal and early life can act synergistically to affect the development of obesity [219].

\subsection{Polyunsaturated Fatty Acids}

Omega-6:omega-3 (n-6:n-3) long-chain polyunsaturated fatty acids (LC-PUFAs) play an important role in the brain's physiological activities. While n-3 regulates neurotransmitter production, transport, and release, n-6 is involved in signal transduction [220-222]. When n-6 intake exceeds n-3 LC-PUFA intake, the former replaces the latter in the neuron membrane, changing function and causing inflammation [223]. Western diet consumption is linked to a greater n-6:n-3 ratio and the increased incidence and prevalence of overweightness and obesity [224]. A high prenatal and perinatal n-6:n-3 LC-PUFA ratio is associated with worsening of ADHD symptoms [225,226] and slower psychomotor and mental development $[227,228]$ and may impair language, cognitive, psychomotor, and social development $[229,230]$ at infant and child stages. Even though lower proportions of n-3 LC-PUFAs in children with neurodevelopmental disorders have been reported, the molecular mechanisms that link LC-PUFA status and behavioral problems are still not fully understood. As gut microbes metabolize PUFAs derived from dietary fat [231-235], which function as a detoxifying mechanism in the gastrointestinal tract [236], and exert anti-inflammatory effects [237-240]; it may be postulated that gut microbial PUFAs are important metabolites in the prenatal and perinatal periods to prevent behavioral problems. Further studies are necessary to elucidate the effects of maternal LC-PUFA status during pre-pregnancy and pregnancy on the maternal and offspring microbiota and their association with neurodevelopmental disorders in childhood.

\subsection{Prebiotics and Probiotics}

According to the Food and Agriculture Organization of the United Nations (FAO) and $\mathrm{WHO}$, probiotics are strictly selected microorganisms which, when adequately administered, provide important improvements to the host's health. Prebiotics, on the other hand, are non-viable food components that provide a health benefit to the host through modulating the microbiota, an alternative to probiotics or as an additional support, improving the survival of probiotic microorganisms, particularly Lactobacilli and Bifidobacterium, in the gastrointestinal tract.

The close relationships between the maternal-fetal gut microbiota axis and health/disease have aroused great interest in exploring probiotics and prebiotics to favorably influence and establish gut microbiota homeostasis [241].

GF mice showed decreased anxiety-like behavior and increased motor activity in studies [242-244] indicating the modulation of conventional gut microbiota has an impact on behavior development, as well as neurochemical changes in the brain. It is possible to improve anxiety and depression using probiotics-based therapy. Oral administration with the human commensal Bacteroides fragilis was able to improve communicative, stereotypic, anxiety-like, and sensorimotor behaviors of the offspring of the maternal immune activation mouse (MIA) model, as well as modify gut permeability and microbial composition. The prenatal administration of oral probiotics protected the offspring from developing ASD-like behaviors induced by maternal immune activation, preventing (i) the increase in the IL-6 and IL-17a levels in both maternal serum and fetal brains, (ii) loss of parvalbumin positive neurons, and (iii) the decrease in $\gamma$-aminobutyric acid levels in adult's offspring prefrontal cortex [245]. Maternal probiotic treatment with Lactobacillus acidophilus and Bifidobacterium infantis modified the neonate's microbiota in C57BL/6J mice, improving the neurodevelopmental outcomes of offspring [246]. At pre-weaned age, maternal supplemen- 
tation reduced postnatal peripheral inflammation, restored impaired blood-brain barrier permeability, and normalized tight junction protein expression. Furthermore, maternal probiotic supplementation influenced leukocyte trans-endothelial migration, extracellular matrix damage, and neuroinflammation. Reduced astrocyte/microglia activation and downregulation of the transcriptional regulators CCAAT/enhancer binding protein delta (CEBPD) and nuclear factor of kappa light polypeptide gene enhancer in B-cells inhibitor, alpha $(I \kappa B \alpha)$, were linked to improved neurodevelopmental outcomes in offspring, probably due to promoted neuronal and oligodendrocyte progenitor cell development [246].

The prebiotic inulin reduced reactive oxygen species levels, protein and lipid peroxidation, and cholinesterase activity in the cerebellum, cortex, and striatum of maternal and fetal brains in a developmental model of rotenone-induced neurotoxicity, suggesting a potential role for indigestible oligosaccharides in reducing oxidative stress-mediated developmental origins of neurodegenerative disease.

In a developmental model of rotenone-induced neurotoxicity, prebiotic inulin reduced reactive oxygen species, protein and lipid peroxidation, and cholinesterase activity in the cortex, cerebellum, and striatum of maternal and fetal brain, suggesting a possible role for indigestible oligosaccharides in reducing oxidative stress-mediated developmental causes of neurodegenerative disorders [247]. Schmidt et al. investigated the effects of the prebiotic Bimuno ${ }^{\circledR}$ galactooligosaccharide on the release of cortisol, stress hormones, and emotional processing in healthy subjects. Ingestion of Bimuno ${ }^{\circledR}$ galactooligosaccharide decreased salivary cortisol awakening response and reduced attentional vigilance to negative versus positive information. The changes in mood may be related to the bifidogenic effects of galactooligosaccharide supplementation [248].

Thus, data collectively support the influence of probiotic and prebiotic intake on gut-brain axis communication via intestinal microbiota alterations, affecting brain function and behavior.

\section{Conclusions}

One promising link between maternal microbiota and offspring neurodevelopmental outcomes is maternal nutrition, as the intrauterine and early life phase are critical early windows in which the colonization of the gut microbiota occurs, which can significantly affect infant health outcomes. Clinical and preclinical studies suggest that maternal nutrition can interact with the natural trajectory of the offspring microbiota and play a role in brain health programming. The neurological system and the intestinal flora have concurrent developmental trajectories, and at this moment, maternal diet patterns can act, leaving a distinctive fingerprint in the infant intestinal microbiota and affecting offspring 's brain function and behavior. Many of the studies included in this review, however, were epidemiological studies, which have issues with validity, accuracy, and interpretation, and frequently fail to show a causal relationship between the phenomena studied. Therefore, further studies that categorically establish a causal relationship between maternal nutrition, offspring microbiota modulation, and its consequences in early life neurodevelopmental disorders are necessary. Understanding the role of maternal diet on microbiota modulation and its consequences on neurodevelopmental outcomes in early life can open new perspectives and potential targets for modulatory interventions of the offspring microbiome, aiming to reduce the risk of neurodevelopmental disease.

Author Contributions: E.N.G.d.S.P. and A.D. contributed to the conception, design, review and writing of the article. Both authors have read and agreed to the published version of the manuscript.

Funding: This research received no external funding.

Institutional Review Board Statement: Not applicable.

Informed Consent Statement: Not applicable.

Acknowledgments: BioRender was used to make all figures.

Conflicts of Interest: The authors declare no conflict of interest. 


\section{References}

1. Bluher, M. Obesity: Global epidemiology and pathogenesis. Nat. Rev. Endocrinol. 2019, 15, 288-298. [CrossRef]

2. W.H.O. Fact Sheet: Obesity and Overweight. Available online: http://www.who.int/mediacentre/factsheets/fs311/en/index.ht $\mathrm{ml}$ (accessed on 28 June 2021).

3. W.H.O. Noncommunicable Diseases Progress Monitor. Available online: https://www.who.int/nmh/publications/ncd-progres s-monitor-2017/en/ (accessed on 28 June 2021).

4. Bale, T.L.; Baram, T.Z.; Brown, A.S.; Goldstein, J.M.; Insel, T.R.; McCarthy, M.M.; Nemeroff, C.B.; Reyes, T.M.; Simerly, R.B.; Susser, E.S.; et al. Early life programming and neurodevelopmental disorders. Biol. Psychiatry 2010, 68, 314-319. [CrossRef]

5. Van Lieshout, R.J.; Taylor, V.H.; Boyle, M.H. Pre-pregnancy and pregnancy obesity and neurodevelopmental outcomes in offspring: A systematic review. Obes. Rev. 2011, 12, e548-e559. [CrossRef] [PubMed]

6. Rivera, H.M.; Christiansen, K.J.; Sullivan, E.L. The role of maternal obesity in the risk of neuropsychiatric disorders. Front. Neurosci. 2015, 9, 194. [CrossRef]

7. Anstey, K.J.; Cherbuin, N.; Budge, M.; Young, J. Body mass index in midlife and late-life as a risk factor for dementia: A meta-analysis of prospective studies. Obes. Rev. 2011, 12, e426-e437. [CrossRef]

8. Huang, L.; Yu, X.; Keim, S.; Li, L.; Zhang, L.; Zhang, J. Maternal prepregnancy obesity and child neurodevelopment in the Collaborative Perinatal Project. Int. J. Epidemiol. 2014, 43, 783-792. [CrossRef]

9. Tanda, R.; Salsberry, P.J.; Reagan, P.B.; Fang, M.Z. The impact of prepregnancy obesity on children's cognitive test scores. Matern. Child Health J. 2013, 17, 222-229. [CrossRef]

10. Hinkle, S.N.; Schieve, L.A.; Stein, A.D.; Swan, D.W.; Ramakrishnan, U.; Sharma, A.J. Associations between maternal prepregnancy body mass index and child neurodevelopment at 2 years of age. Int. J. Obes. 2012, 36, 1312-1319. [CrossRef]

11. Heikura, U.; Taanila, A.; Hartikainen, A.L.; Olsen, P.; Linna, S.L.; von Wendt, L.; Jarvelin, M.R. Variations in prenatal sociodemographic factors associated with intellectual disability: A study of the 20-year interval between two birth cohorts in northern Finland. Am. J. Epidemiol. 2008, 167, 169-177. [CrossRef]

12. Krakowiak, P.; Walker, C.K.; Bremer, A.A.; Baker, A.S.; Ozonoff, S.; Hansen, R.L.; Hertz-Picciotto, I. Maternal metabolic conditions and risk for autism and other neurodevelopmental disorders. Pediatrics 2012, 129, e1121-e1128. [CrossRef]

13. Li, M.; Fallin, M.D.; Riley, A.; Landa, R.; Walker, S.O.; Silverstein, M.; Caruso, D.; Pearson, C.; Kiang, S.; Dahm, J.L.; et al. The Association of Maternal Obesity and Diabetes With Autism and Other Developmental Disabilities. Pediatrics 2016, 137, e20152206. [CrossRef] [PubMed]

14. Reynolds, L.C.; Inder, T.E.; Neil, J.J.; Pineda, R.G.; Rogers, C.E. Maternal obesity and increased risk for autism and developmental delay among very preterm infants. J. Perinatol. 2014, 34, 688-692. [CrossRef] [PubMed]

15. Dodds, L.; Fell, D.B.; Shea, S.; Armson, B.A.; Allen, A.C.; Bryson, S. The role of prenatal, obstetric and neonatal factors in the development of autism. J. Autism Dev. Disord. 2011, 41, 891-902. [CrossRef] [PubMed]

16. Walker, C.K.; Krakowiak, P.; Baker, A.; Hansen, R.L.; Ozonoff, S.; Hertz-Picciotto, I. Preeclampsia, placental insufficiency, and autism spectrum disorder or developmental delay. JAMA Pediatr. 2015, 169, 154-162. [CrossRef]

17. Rodriguez, A.; Miettunen, J.; Henriksen, T.B.; Olsen, J.; Obel, C.; Taanila, A.; Ebeling, H.; Linnet, K.M.; Moilanen, I.; Jarvelin, M.R. Maternal adiposity prior to pregnancy is associated with ADHD symptoms in offspring: Evidence from three prospective pregnancy cohorts. Int. J. Obes. 2008, 32, 550-557. [CrossRef]

18. Buss, C.; Entringer, S.; Davis, E.P.; Hobel, C.J.; Swanson, J.M.; Wadhwa, P.D.; Sandman, C.A. Impaired executive function mediates the association between maternal pre-pregnancy body mass index and child ADHD symptoms. PLoS ONE 2012, 7, e37758. [CrossRef]

19. Chen, Q.; Sjolander, A.; Langstrom, N.; Rodriguez, A.; Serlachius, E.; D'Onofrio, B.M.; Lichtenstein, P.; Larsson, H. Maternal pre-pregnancy body mass index and offspring attention deficit hyperactivity disorder: A population-based cohort study using a sibling-comparison design. Int. J. Epidemiol. 2014, 43, 83-90. [CrossRef]

20. Rodriguez, A. Maternal pre-pregnancy obesity and risk for inattention and negative emotionality in children. J. Child Psychol. Psychiatry 2010, 51, 134-143. [CrossRef]

21. Parenti, I.; Rabaneda, L.G.; Schoen, H.; Novarino, G. Neurodevelopmental Disorders: From Genetics to Functional Pathways. Trends Neurosci. 2020, 43, 608-621. [CrossRef]

22. De Felice, A.; Ricceri, L.; Venerosi, A.; Chiarotti, F.; Calamandrei, G. Multifactorial Origin of Neurodevelopmental Disorders: Approaches to Understanding Complex Etiologies. Toxics 2015, 3, 89-129. [CrossRef]

23. Dinan, T.G.; Stilling, R.M.; Stanton, C.; Cryan, J.F. Collective unconscious: How gut microbes shape human behavior. J. Psychiatr. Res. 2015, 63, 1-9. [CrossRef]

24. Gonzalez, A.; Stombaugh, J.; Lozupone, C.; Turnbaugh, P.J.; Gordon, J.I.; Knight, R. The mind-body-microbial continuum. Dialogues Clin. Neurosci. 2011, 13, 55-62. [PubMed]

25. Adlerberth, I.; Wold, A.E. Establishment of the gut microbiota in Western infants. Acta Paediatr. 2009, 98, 229-238. [CrossRef]

26. Diaz Heijtz, R. Fetal, neonatal, and infant microbiome: Perturbations and subsequent effects on brain development and behavior. Semin. Fetal Neonatal. Med. 2016, 21, 410-417. [CrossRef]

27. de Weerth, C. Do bacteria shape our development? Crosstalk between intestinal microbiota and HPA axis. Neurosci. Biobehav. Rev. 2017, 83, 458-471. [CrossRef] [PubMed] 
28. Nicholson, J.K.; Holmes, E.; Kinross, J.; Burcelin, R.; Gibson, G.; Jia, W.; Pettersson, S. Host-gut microbiota metabolic interactions. Science 2012, 336, 1262-1267. [CrossRef] [PubMed]

29. Tremaroli, V.; Backhed, F. Functional interactions between the gut microbiota and host metabolism. Nature 2012, 489, 242-249. [CrossRef] [PubMed]

30. Du, Y.; Gao, X.R.; Peng, L.; Ge, J.F. Crosstalk between the microbiota-gut-brain axis and depression. Heliyon 2020,6 , e04097. [CrossRef] [PubMed]

31. Caputi, V.; Giron, M.C. Microbiome-Gut-Brain Axis and Toll-Like Receptors in Parkinson's Disease. Int J. Mol. Sci 2018, 19, 1689. [CrossRef]

32. Foster, J.A.; McVey Neufeld, K.A. Gut-brain axis: How the microbiome influences anxiety and depression. Trends Neurosci. 2013, 36, 305-312. [CrossRef]

33. Raspini, B.; Vacca, M.; Porri, D.; De Giuseppe, R.; Calabrese, F.M.; Chieppa, M.; Liso, M.; Cerbo, R.M.; Civardi, E.; Garofoli, F.; et al. Early Life Microbiota Colonization at Six Months of Age: A Transitional Time Point. Front. Cell Infect. Microbiol. 2021, 11, 590202. [CrossRef] [PubMed]

34. Aagaard, K.; Ma, J.; Antony, K.M.; Ganu, R.; Petrosino, J.; Versalovic, J. The placenta harbors a unique microbiome. Sci. Transl. Med. 2014, 6, 237ra65. [CrossRef] [PubMed]

35. Jimenez, E.; Marin, M.L.; Martin, R.; Odriozola, J.M.; Olivares, M.; Xaus, J.; Fernandez, L.; Rodriguez, J.M. Is meconium from healthy newborns actually sterile? Res. Microbiol. 2008, 159, 187-193. [CrossRef] [PubMed]

36. de Goffau, M.C.; Lager, S.; Sovio, U.; Gaccioli, F.; Cook, E.; Peacock, S.J.; Parkhill, J.; Charnock-Jones, D.S.; Smith, G.C.S. Human placenta has no microbiome but can contain potential pathogens. Nature 2019, 572, 329-334. [CrossRef]

37. Zhou, L.; Xiao, X. The role of gut microbiota in the effects of maternal obesity during pregnancy on offspring metabolism. Biosci. Rep. 2018, 38, 1821-1830. [CrossRef]

38. Favier, C.F.; de Vos, W.M.; Akkermans, A.D. Development of bacterial and bifidobacterial communities in feces of newborn babies. Anaerobe 2003, 9, 219-229. [CrossRef] [PubMed]

39. Makino, H.; Kushiro, A.; Ishikawa, E.; Kubota, H.; Gawad, A.; Sakai, T.; Oishi, K.; Martin, R.; Ben-Amor, K.; Knol, J.; et al. Mother-to-infant transmission of intestinal bifidobacterial strains has an impact on the early development of vaginally delivered infant's microbiota. PLoS ONE 2013, 8, e78331. [CrossRef] [PubMed]

40. Dominguez-Bello, M.G.; Costello, E.K.; Contreras, M.; Magris, M.; Hidalgo, G.; Fierer, N.; Knight, R. Delivery mode shapes the acquisition and structure of the initial microbiota across multiple body habitats in newborns. Proc. Natl. Acad. Sci. USA 2010, 107, 11971-11975. [CrossRef] [PubMed]

41. Bokulich, N.A.; Chung, J.; Battaglia, T.; Henderson, N.; Jay, M.; Li, H.; Lieber, A.D.; Wu, F.; Perez-Perez, G.I.; Chen, Y.; et al. Antibiotics, birth mode, and diet shape microbiome maturation during early life. Sci. Transl. Med. 2016, 8, 343ra82. [CrossRef]

42. Tun, H.M.; Bridgman, S.L.; Chari, R.; Field, C.J.; Guttman, D.S.; Becker, A.B.; Mandhane, P.J.; Turvey, S.E.; Subbarao, P.; Sears, M.R.; et al. Roles of Birth Mode and Infant Gut Microbiota in Intergenerational Transmission of Overweight and Obesity From Mother to Offspring. JAMA Pediatr. 2018, 172, 368-377. [CrossRef]

43. Collado, M.C.; Isolauri, E.; Laitinen, K.; Salminen, S. Effect of mother's weight on infant's microbiota acquisition, composition, and activity during early infancy: A prospective follow-up study initiated in early pregnancy. Am. J. Clin. Nutr. 2010, 92, 1023-1030. [CrossRef]

44. Sanchez, C.E.; Barry, C.; Sabhlok, A.; Russell, K.; Majors, A.; Kollins, S.H.; Fuemmeler, B.F. Maternal pre-pregnancy obesity and child neurodevelopmental outcomes: A meta-analysis. Obes. Rev. 2018, 19, 464-484. [CrossRef] [PubMed]

45. Ornoy, A.; Ratzon, N.; Greenbaum, C.; Wolf, A.; Dulitzky, M. School-age children born to diabetic mothers and to mothers with gestational diabetes exhibit a high rate of inattention and fine and gross motor impairment. J. Pediatr. Endocrinol. Metab. 2001, 14 (Suppl. 1), 681-689. [CrossRef] [PubMed]

46. Connolly, N.; Anixt, J.; Manning, P.; Ping, I.L.D.; Marsolo, K.A.; Bowers, K. Maternal metabolic risk factors for autism spectrum disorder-An analysis of electronic medical records and linked birth data. Autism Res. 2016, 9, 829-837. [CrossRef] [PubMed]

47. Rizzo, T.A.; Dooley, S.L.; Metzger, B.E.; Cho, N.H.; Ogata, E.S.; Silverman, B.L. Prenatal and perinatal influences on long-term psychomotor development in offspring of diabetic mothers. Am. J. Obstet. Gynecol. 1995, 173, 1753-1758. [CrossRef]

48. Musser, E.D.; Willoughby, M.T.; Wright, S.; Sullivan, E.L.; Stadler, D.D.; Olson, B.F.; Steiner, R.D.; Nigg, J.T. Maternal prepregnancy body mass index and offspring attention-deficit/hyperactivity disorder: A quasi-experimental sibling-comparison, populationbased design. J. Child. Psychol. Psychiatry 2017, 58, 240-247. [CrossRef]

49. McDonald, S.D.; Han, Z.; Mulla, S.; Beyene, J.; Knowledge Synthesis, G. Overweight and obesity in mothers and risk of preterm birth and low birth weight infants: Systematic review and meta-analyses. BMJ 2010, 341, c3428. [CrossRef]

50. Bhutta, A.T.; Cleves, M.A.; Casey, P.H.; Cradock, M.M.; Anand, K.J. Cognitive and behavioral outcomes of school-aged children who were born preterm: A meta-analysis. JAMA 2002, 288, 728-737. [CrossRef]

51. Allotey, J.; Zamora, J.; Cheong-See, F.; Kalidindi, M.; Arroyo-Manzano, D.; Asztalos, E.; van der Post, J.; Mol, B.W.; Moore, D.; Birtles, D.; et al. Cognitive, motor, behavioural and academic performances of children born preterm: A meta-analysis and systematic review involving 64061 children. BJOG 2018, 125, 16-25. [CrossRef]

52. van Mil, N.H.; Steegers-Theunissen, R.P.; Motazedi, E.; Jansen, P.W.; Jaddoe, V.W.; Steegers, E.A.; Verhulst, F.C.; Tiemeier, H. Low and high birth weight and the risk of child attention problems. J. Pediatr. 2015, 166, 862-869.e3. [CrossRef]

53. Fandriks, L. Roles of the gut in the metabolic syndrome: An overview. J. Intern. Med. 2017, 281, 319-336. [CrossRef] 
54. Mente, A.; Dehghan, M.; Rangarajan, S.; McQueen, M.; Dagenais, G.; Wielgosz, A.; Lear, S.; Li, W.; Chen, H.; Yi, S.; et al. Association of dietary nutrients with blood lipids and blood pressure in 18 countries: A cross-sectional analysis from the PURE study. Lancet Diabetes Endocrinol. 2017, 5, 774-787. [CrossRef]

55. Codagnone, M.G.; Stanton, C.; O’Mahony, S.M.; Dinan, T.G.; Cryan, J.F. Microbiota and Neurodevelopmental Trajectories: Role of Maternal and Early-Life Nutrition. Ann. Nutr. Metab. 2019, 74 (Suppl. 2), 16-27. [CrossRef] [PubMed]

56. Sonnenburg, J.L.; Backhed, F. Diet-microbiota interactions as moderators of human metabolism. Nature 2016, 535, 56-64. [CrossRef] [PubMed]

57. Jeffery, I.B.; O'Toole, P.W. Diet-microbiota interactions and their implications for healthy living. Nutrients 2013, 5, $234-252$. [CrossRef] [PubMed]

58. Korem, T.; Zeevi, D.; Suez, J.; Weinberger, A.; Avnit-Sagi, T.; Pompan-Lotan, M.; Matot, E.; Jona, G.; Harmelin, A.; Cohen, N.; et al. Growth dynamics of gut microbiota in health and disease inferred from single metagenomic samples. Science 2015, 349, 1101-1106. [CrossRef]

59. Lundgren, S.N.; Madan, J.C.; Emond, J.A.; Morrison, H.G.; Christensen, B.C.; Karagas, M.R.; Hoen, A.G. Maternal diet during pregnancy is related with the infant stool microbiome in a delivery mode-dependent manner. Microbiome 2018, 6, 109. [CrossRef]

60. American Association of Neurological Surgeons (AANS); American Society of Neuroradiology (ASNR); Cardiovascular and Interventional Radiology Society of Europe (CIRSE); Canadian Interventional Radiology Association (CIRA); Congress of Neurological Surgeons (CNS); European Society of Minimally Invasive Neurological Therapy (ESMINT); European Society of Neuroradiology (ESNR); European Stroke Organization (ESO); Society for Cardiovascular Angiography and Interventions (SCAI); Society of Interventional Radiology (SIR); et al. Multisociety Consensus Quality Improvement Revised Consensus Statement for Endovascular Therapy of Acute Ischemic Stroke. Int. J. Stroke 2018, 13, 612-632. [CrossRef]

61. Mulligan, C.M.; Friedman, J.E. Maternal modifiers of the infant gut microbiota: Metabolic consequences. J. Endocrinol. 2017, 235, R1-R12. [CrossRef]

62. Gluckman, P.D.; Hanson, M.A.; Cooper, C.; Thornburg, K.L. Effect of in utero and early-life conditions on adult health and disease. N. Engl. J. Med. 2008, 359, 61-73. [CrossRef]

63. Heerwagen, M.J.; Miller, M.R.; Barbour, L.A.; Friedman, J.E. Maternal obesity and fetal metabolic programming: A fertile epigenetic soil. Am. J. Physiol. Regul. Integr. Comp. Physiol. 2010, 299, R711-R722. [CrossRef] [PubMed]

64. Wesolowski, S.R.; Kasmi, K.C.; Jonscher, K.R.; Friedman, J.E. Developmental origins of NAFLD: A womb with a clue. Nat. Rev. Gastroenterol. Hepatol. 2017, 14, 81-96. [CrossRef]

65. Eriksson, J.G.; Sandboge, S.; Salonen, M.K.; Kajantie, E.; Osmond, C. Long-term consequences of maternal overweight in pregnancy on offspring later health: Findings from the Helsinki Birth Cohort Study. Ann. Med. 2014, 46, 434-438. [CrossRef] [PubMed]

66. Gaillard, R.; Steegers, E.A.; Duijts, L.; Felix, J.F.; Hofman, A.; Franco, O.H.; Jaddoe, V.W. Childhood cardiometabolic outcomes of maternal obesity during pregnancy: The Generation R Study. Hypertension 2014, 63, 683-691. [CrossRef] [PubMed]

67. Hussen, H.I.; Persson, M.; Moradi, T. Maternal overweight and obesity are associated with increased risk of type 1 diabetes in offspring of parents without diabetes regardless of ethnicity. Diabetologia 2015, 58, 1464-1473. [CrossRef]

68. David, L.A.; Maurice, C.F.; Carmody, R.N.; Gootenberg, D.B.; Button, J.E.; Wolfe, B.E.; Ling, A.V.; Devlin, A.S.; Varma, Y.; Fischbach, M.A.; et al. Diet rapidly and reproducibly alters the human gut microbiome. Nature 2014, 505, 559-563. [CrossRef] [PubMed]

69. Turnbaugh, P.J.; Ley, R.E.; Mahowald, M.A.; Magrini, V.; Mardis, E.R.; Gordon, J.I. An obesity-associated gut microbiome with increased capacity for energy harvest. Nature 2006, 444, 1027-1031. [CrossRef]

70. Buffington, S.A.; Di Prisco, G.V.; Auchtung, T.A.; Ajami, N.J.; Petrosino, J.F.; Costa-Mattioli, M. Microbial Reconstitution Reverses Maternal Diet-Induced Social and Synaptic Deficits in Offspring. Cell 2016, 165, 1762-1775. [CrossRef] [PubMed]

71. Zacarias, M.F.; Collado, M.C.; Gomez-Gallego, C.; Flinck, H.; Aittoniemi, J.; Isolauri, E.; Salminen, S. Pregestational overweight and obesity are associated with differences in gut microbiota composition and systemic inflammation in the third trimester. PLoS ONE 2018, 13, e0200305. [CrossRef]

72. Monk, C.; Georgieff, M.K.; Osterholm, E.A. Research review: Maternal prenatal distress and poor nutrition-Mutually influencing risk factors affecting infant neurocognitive development. J. Child Psychol. Psychiatry 2013, 54, 115-130. [CrossRef]

73. Reddavide, R.; Rotolo, O.; Caruso, M.G.; Stasi, E.; Notarnicola, M.; Miraglia, C.; Nouvenne, A.; Meschi, T.; De'Angelis, G.L.; Di Mario, F; et al. The role of diet in the prevention and treatment of Inflammatory Bowel Diseases. Acta Biomed. 2018, 89, 60-75. [CrossRef]

74. Steegenga, W.T.; Mischke, M.; Lute, C.; Boekschoten, M.V.; Lendvai, A.; Pruis, M.G.; Verkade, H.J.; van de Heijning, B.J.; Boekhorst, J.; Timmerman, H.M.; et al. Maternal exposure to a Western-style diet causes differences in intestinal microbiota composition and gene expression of suckling mouse pups. Mol. Nutr. Food Res. 2017, 61, 1600141. [CrossRef]

75. Gohir, W.; Whelan, F.J.; Surette, M.G.; Moore, C.; Schertzer, J.D.; Sloboda, D.M. Pregnancy-related changes in the maternal gut microbiota are dependent upon the mother's periconceptional diet. Gut Microbes 2015, 6, 310-320. [CrossRef]

76. Chu, D.M.; Antony, K.M.; Ma, J.; Prince, A.L.; Showalter, L.; Moller, M.; Aagaard, K.M. The early infant gut microbiome varies in association with a maternal high-fat diet. Genome Med. 2016, 8, 77. [CrossRef] 
77. Val-Laillet, D.; Besson, M.; Guerin, S.; Coquery, N.; Randuineau, G.; Kanzari, A.; Quesnel, H.; Bonhomme, N.; Bolhuis, J.E.; Kemp, B.; et al. A maternal Western diet during gestation and lactation modifies offspring's microbiota activity, blood lipid levels, cognitive responses, and hippocampal neurogenesis in Yucatan pigs. FASEB J. 2017, 31, 2037-2049. [CrossRef]

78. Perani, C.V.; Neumann, I.D.; Reber, S.O.; Slattery, D.A. High-fat diet prevents adaptive peripartum-associated adrenal gland plasticity and anxiolysis. Sci. Rep. 2015, 5, 14821. [CrossRef]

79. Grissom, N.M.; George, R.; Reyes, T.M. The hypothalamic transcriptional response to stress is severely impaired in offspring exposed to adverse nutrition during gestation. Neuroscience 2017, 342, 200-211. [CrossRef]

80. Betran, A.P.; Torloni, M.R.; Zhang, J.J.; Gulmezoglu, A.M.; WHO Working Group on Caesarean Section. WHO Statement on Caesarean Section Rates. BJOG 2016, 123, 667-670. [CrossRef]

81. Reyman, M.; van Houten, M.A.; van Baarle, D.; Bosch, A.; Man, W.H.; Chu, M.; Arp, K.; Watson, R.L.; Sanders, E.A.M.; Fuentes, S.; et al. Impact of delivery mode-associated gut microbiota dynamics on health in the first year of life. Nat. Commun. 2019, 10, 4997. [CrossRef]

82. Zhang, T.; Sidorchuk, A.; Sevilla-Cermeno, L.; Vilaplana-Perez, A.; Chang, Z.; Larsson, H.; Mataix-Cols, D.; Fernandez de la Cruz, L. Association of Cesarean Delivery With Risk of Neurodevelopmental and Psychiatric Disorders in the Offspring: A Systematic Review and Meta-analysis. JAMA Netw. Open 2019, 2, e1910236. [CrossRef] [PubMed]

83. Curran, E.A.; O’Neill, S.M.; Cryan, J.F.; Kenny, L.C.; Dinan, T.G.; Khashan, A.S.; Kearney, P.M. Research review: Birth by caesarean section and development of autism spectrum disorder and attention-deficit/hyperactivity disorder: A systematic review and meta-analysis. J. Child Psychol. Psychiatry 2015, 56, 500-508. [CrossRef]

84. Axelsson, P.B.; Clausen, T.D.; Petersen, A.H.; Hageman, I.; Pinborg, A.; Kessing, L.V.; Bergholt, T.; Rasmussen, S.C.; Keiding, N.; Lokkegaard, E.C.L. Investigating the effects of cesarean delivery and antibiotic use in early childhood on risk of later attention deficit hyperactivity disorder. J. Child Psychol. Psychiatry 2019, 60, 151-159. [CrossRef]

85. Curran, E.A.; Khashan, A.S.; Dalman, C.; Kenny, L.C.; Cryan, J.F.; Dinan, T.G.; Kearney, P.M. Obstetric mode of delivery and attention-deficit/hyperactivity disorder: A sibling-matched study. Int. J. Epidemiol. 2016, 45, 532-542. [CrossRef]

86. Curran, E.A.; Dalman, C.; Kearney, P.M.; Kenny, L.C.; Cryan, J.F.; Dinan, T.G.; Khashan, A.S. Association Between Obstetric Mode of Delivery and Autism Spectrum Disorder: A Population-Based Sibling Design Study. JAMA Psychiatry 2015, 72, 935-942. [CrossRef]

87. Axelsson, P.B.; Clausen, T.D.; Petersen, A.H.; Hageman, I.; Pinborg, A.; Kessing, L.V.; Bergholt, T.; Rasmussen, S.C.; Keiding, N.; Lokkegaard, E.C.L. Relation Between Infant Microbiota and Autism: Results from a National Cohort Sibling Design Study. Epidemiology 2019, 30, 52-60. [CrossRef]

88. Zhang, T.; Brander, G.; Mantel, A.; Kuja-Halkola, R.; Stephansson, O.; Chang, Z.; Larsson, H.; Mataix-Cols, D.; Fernandez de la Cruz, L. Assessment of Cesarean Delivery and Neurodevelopmental and Psychiatric Disorders in the Children of a Population-Based Swedish Birth Cohort. JAMA Netw. Open 2021, 4, e210837. [CrossRef]

89. Sole, E.; Roca, A.; Torres, A.; Hernandez, A.S.; Fernandez, N.; Diaz, C.N.; Vieta, E.; Garcia-Esteve, L. Obstetric complications in bipolar disorder: Psychiatric factors and the risk of caesarean section. Eur. Neuropsychopharmacol. 2020, 32, 47-55. [CrossRef]

90. Sydsjo, G.; Moller, L.; Lilliecreutz, C.; Bladh, M.; Andolf, E.; Josefsson, A. Psychiatric illness in women requesting caesarean section. BJOG 2015, 122, 351-358. [CrossRef]

91. Stokholm, J.; Thorsen, J.; Chawes, B.L.; Schjorring, S.; Krogfelt, K.A.; Bonnelykke, K.; Bisgaard, H. Cesarean section changes neonatal gut colonization. J. Allergy Clin. Immunol. 2016, 138, 881-889.e2. [CrossRef]

92. Adlerberth, I.; Lindberg, E.; Aberg, N.; Hesselmar, B.; Saalman, R.; Strannegard, I.L.; Wold, A.E. Reduced enterobacterial and increased staphylococcal colonization of the infantile bowel: An effect of hygienic lifestyle? Pediatr. Res. 2006, 59, 96-101. [CrossRef]

93. Fukuda, S.; Toh, H.; Hase, K.; Oshima, K.; Nakanishi, Y.; Yoshimura, K.; Tobe, T.; Clarke, J.M.; Topping, D.L.; Suzuki, T.; et al. Bifidobacteria can protect from enteropathogenic infection through production of acetate. Nature 2011, 469, 543-547. [CrossRef] [PubMed]

94. Gronlund, M.M.; Lehtonen, O.P.; Eerola, E.; Kero, P. Fecal microflora in healthy infants born by different methods of delivery: Permanent changes in intestinal flora after cesarean delivery. J. Pediatr. Gastroenterol. Nutr. 1999, 28, 19-25. [CrossRef]

95. Adler, S.A.; Wong-Kee-You, A.M. Differential attentional responding in caesarean versus vaginally delivered infants. Atten. Percept. Psychophys. 2015, 77, 2529-2539. [CrossRef]

96. Al Khalaf, S.Y.; O’Neill, S.M.; O'Keeffe, L.M.; Henriksen, T.B.; Kenny, L.C.; Cryan, J.F.; Khashan, A.S. The impact of obstetric mode of delivery on childhood behavior. Soc. Psychiatry Psychiatr. Epidemiol. 2015, 50, 1557-1567. [CrossRef]

97. Neu, J. Dysbiosis in the Neonatal Period: Role of Cesarean Section. Nestle Nutr. Inst. Workshop Ser. 2017, 88, 57-66. [CrossRef] [PubMed]

98. Moya-Perez, A.; Luczynski, P.; Renes, I.B.; Wang, S.; Borre, Y.; Anthony Ryan, C.; Knol, J.; Stanton, C.; Dinan, T.G.; Cryan, J.F. Intervention strategies for cesarean section-induced alterations in the microbiota-gut-brain axis. Nutr. Rev. 2017, 75, 225-240. [CrossRef]

99. Morais, L.H.; Golubeva, A.V.; Moloney, G.M.; Moya-Perez, A.; Ventura-Silva, A.P.; Arboleya, S.; Bastiaanssen, T.F.S.; O'Sullivan, O.; Rea, K.; Borre, Y.; et al. Enduring Behavioral Effects Induced by Birth by Caesarean Section in the Mouse. Curr. Biol. 2020, 30, 3761-3774.e6. [CrossRef] 
100. Rutayisire, E.; Wu, X.; Huang, K.; Tao, S.; Chen, Y.; Tao, F. Cesarean section may increase the risk of both overweight and obesity in preschool children. BMC Pregnancy Childbirth 2016, 16, 338. [CrossRef]

101. Zhao, J.; Grant, S.F. Genetics of childhood obesity. J. Obes. 2011, 2011, 845148. [CrossRef]

102. Chung, K.H.; Chiou, H.Y.; Chen, Y.H. Psychological and physiological correlates of childhood obesity in Taiwan. Sci. Rep. 2015, 5, 17439. [CrossRef]

103. Favaro, A.; Santonastaso, P. Effects of parents' psychological characteristics and eating behaviour on childhood obesity and dietary compliance. J. Psychosom. Res. 1995, 39, 145-151. [CrossRef]

104. Collins, S.M.; Surette, M.; Bercik, P. The interplay between the intestinal microbiota and the brain. Nat. Rev. Microbiol. 2012, 10, 735-742. [CrossRef]

105. Cryan, J.F.; Dinan, T.G. Mind-altering microorganisms: The impact of the gut microbiota on brain and behaviour. Nat. Rev. Neurosci. 2012, 13, 701-712. [CrossRef] [PubMed]

106. Sampson, T.R.; Mazmanian, S.K. Control of brain development, function, and behavior by the microbiome. Cell Host Microbe 2015, 17, 565-576. [CrossRef]

107. Borre, Y.E.; O'Keeffe, G.W.; Clarke, G.; Stanton, C.; Dinan, T.G.; Cryan, J.F. Microbiota and neurodevelopmental windows: Implications for brain disorders. Trends Mol. Med. 2014, 20, 509-518. [CrossRef] [PubMed]

108. Polidano, C.; Zhu, A.; Bornstein, J.C. The relation between cesarean birth and child cognitive development. Sci. Rep. 2017, 7, 11483. [CrossRef]

109. WHO Organization. The Optimal Duration of Exclusive Breastfeeding: Report of an Expert Consultation; WHO Organization: Geneva, Switzerland, 2001.

110. Section on Breastfeeding. Breastfeeding and the use of human milk. Pediatrics 2012, 129, e827-e841. [CrossRef]

111. Bar, S.; Milanaik, R.; Adesman, A. Long-term neurodevelopmental benefits of breastfeeding. Curr. Opin. Pediatr. 2016, 28 , 559-566. [CrossRef] [PubMed]

112. Uvnas Moberg, K.; Ekstrom-Bergstrom, A.; Buckley, S.; Massarotti, C.; Pajalic, Z.; Luegmair, K.; Kotlowska, A.; Lengler, L.; Olza, I.; Grylka-Baeschlin, S.; et al. Maternal plasma levels of oxytocin during breastfeeding-A systematic review. PLoS ONE 2020, 15, e0235806. [CrossRef]

113. Zetterstrom, R. Breastfeeding and infant-mother interaction. Acta Paediatr. Suppl. 1999, 88, 1-6. [CrossRef]

114. Fergusson, D.M.; Woodward, L.J. Breast feeding and later psychosocial adjustment. Paediatr. Perinat. Epidemiol. 1999, 13, $144-157$. [CrossRef]

115. Tharner, A.; Luijk, M.P.; Raat, H.; Ijzendoorn, M.H.; Bakermans-Kranenburg, M.J.; Moll, H.A.; Jaddoe, V.W.; Hofman, A.; Verhulst, F.C.; Tiemeier, H. Breastfeeding and its relation to maternal sensitivity and infant attachment. J. Dev. Behav. Pediatr. 2012, 33, 396-404. [CrossRef]

116. Knol, J.; Scholtens, P.; Kafka, C.; Steenbakkers, J.; Gro, S.; Helm, K.; Klarczyk, M.; Schopfer, H.; Bockler, H.M.; Wells, J. Colon microflora in infants fed formula with galacto- and fructo-oligosaccharides: More like breast-fed infants. J. Pediatr. Gastroenterol. Nutr. 2005, 40, 36-42. [CrossRef]

117. McDonald, B.; McCoy, K.D. Maternal microbiota in pregnancy and early life. Science 2019, 365, 984-985. [CrossRef]

118. Savage, J.H.; Lee-Sarwar, K.A.; Sordillo, J.E.; Lange, N.E.; Zhou, Y.; O'Connor, G.T.; Sandel, M.; Bacharier, L.B.; Zeiger, R.; Sodergren, E.; et al. Diet during Pregnancy and Infancy and the Infant Intestinal Microbiome. J. Pediatr. 2018, 203, 47-54.e4. [CrossRef] [PubMed]

119. Martin, V.; Maldonado-Barragan, A.; Moles, L.; Rodriguez-Banos, M.; Campo, R.D.; Fernandez, L.; Rodriguez, J.M.; Jimenez, E. Sharing of bacterial strains between breast milk and infant feces. J. Hum. Lact. 2012, 28, 36-44. [CrossRef]

120. Murphy, K.; Curley, D.; O'Callaghan, T.F.; O’Shea, C.A.; Dempsey, E.M.; O’Toole, P.W.; Ross, R.P.; Ryan, C.A.; Stanton, C. The Composition of Human Milk and Infant Faecal Microbiota over the First Three Months of Life: A Pilot Study. Sci. Rep. 2017, 7, 40597. [CrossRef] [PubMed]

121. Cacho, N.T.; Harrison, N.A.; Parker, L.A.; Padgett, K.A.; Lemas, D.J.; Marcial, G.E.; Li, N.; Carr, L.E.; Neu, J.; Lorca, G.L. Personalization of the Microbiota of Donor Human Milk with Mother's Own Milk. Front. Microbiol. 2017, 8, 1470. [CrossRef] [PubMed]

122. Hunt, K.M.; Preuss, J.; Nissan, C.; Davlin, C.A.; Williams, J.E.; Shafii, B.; Richardson, A.D.; McGuire, M.K.; Bode, L.; McGuire, M.A. Human milk oligosaccharides promote the growth of staphylococci. Appl. Environ. Microbiol. 2012, 78, 4763-4770. [CrossRef]

123. Jimenez, E.; Fernandez, L.; Maldonado, A.; Martin, R.; Olivares, M.; Xaus, J.; Rodriguez, J.M. Oral administration of Lactobacillus strains isolated from breast milk as an alternative for the treatment of infectious mastitis during lactation. Appl. Environ. Microbiol. 2008, 74, 4650-4655. [CrossRef]

124. Balmer, S.E.; Wharton, B.A. Diet and faecal flora in the newborn: Breast milk and infant formula. Arch. Dis. Child. 1989, 64, 1672-1677. [CrossRef]

125. Jimenez, E.; Delgado, S.; Maldonado, A.; Arroyo, R.; Albujar, M.; Garcia, N.; Jariod, M.; Fernandez, L.; Gomez, A.; Rodriguez, J.M. Staphylococcus epidermidis: A differential trait of the fecal microbiota of breast-fed infants. BMC Microbiol. $2008,8,143$. [CrossRef]

126. Iwase, T.; Uehara, Y.; Shinji, H.; Tajima, A.; Seo, H.; Takada, K.; Agata, T.; Mizunoe, Y. Staphylococcus epidermidis Esp inhibits Staphylococcus aureus biofilm formation and nasal colonization. Nature 2010, 465, 346-349. [CrossRef] [PubMed] 
127. Park, B.; Iwase, T.; Liu, G.Y. Intranasal application of S. epidermidis prevents colonization by methicillin-resistant Staphylococcus aureus in mice. PLoS ONE 2011, 6, e25880. [CrossRef] [PubMed]

128. Penders, J.; Thijs, C.; Vink, C.; Stelma, F.F.; Snijders, B.; Kummeling, I.; van den Brandt, P.A.; Stobberingh, E.E. Factors influencing the composition of the intestinal microbiota in early infancy. Pediatrics 2006, 118, 511-521. [CrossRef] [PubMed]

129. Stewart, C.J.; Ajami, N.J.; O’Brien, J.L.; Hutchinson, D.S.; Smith, D.P.; Wong, M.C.; Ross, M.C.; Lloyd, R.E.; Doddapaneni, H.; Metcalf, G.A.; et al. Temporal development of the gut microbiome in early childhood from the TEDDY study. Nature 2018, 562, 583-588. [CrossRef]

130. Bezirtzoglou, E.; Tsiotsias, A.; Welling, G.W. Microbiota profile in feces of breast- and formula-fed newborns by using fluorescence in situ hybridization (FISH). Anaerobe 2011, 17, 478-482. [CrossRef]

131. Panagos, P.G.; Vishwanathan, R.; Penfield-Cyr, A.; Matthan, N.R.; Shivappa, N.; Wirth, M.D.; Hebert, J.R.; Sen, S. Breastmilk from obese mothers has pro-inflammatory properties and decreased neuroprotective factors. J. Perinatol. 2016, 36, 284-290. [CrossRef]

132. Innis, S.M. Fatty acids and early human development. Early Hum. Dev. 2007, 83, 761-766. [CrossRef]

133. Tarr, A.J.; Galley, J.D.; Fisher, S.E.; Chichlowski, M.; Berg, B.M.; Bailey, M.T. The prebiotics 3'Sialyllactose and 6'Sialyllactose diminish stressor-induced anxiety-like behavior and colonic microbiota alterations: Evidence for effects on the gut-brain axis. Brain Behav. Immun. 2015, 50, 166-177. [CrossRef]

134. Backhed, F.; Ding, H.; Wang, T.; Hooper, L.V.; Koh, G.Y.; Nagy, A.; Semenkovich, C.F.; Gordon, J.I. The gut microbiota as an environmental factor that regulates fat storage. Proc. Natl. Acad. Sci. USA 2004, 101, 15718-15723. [CrossRef]

135. Pascale, A.; Marchesi, N.; Marelli, C.; Coppola, A.; Luzi, L.; Govoni, S.; Giustina, A.; Gazzaruso, C. Microbiota and metabolic diseases. Endocrine 2018, 61, 357-371. [CrossRef]

136. Davis, C.D. The Gut Microbiome and Its Role in Obesity. Nutr. Today 2016, 51, 167-174. [CrossRef]

137. Donohoe, D.R.; Garge, N.; Zhang, X.; Sun, W.; O'Connell, T.M.; Bunger, M.K.; Bultman, S.J. The microbiome and butyrate regulate energy metabolism and autophagy in the mammalian colon. Cell Metab. 2011, 13, 517-526. [CrossRef]

138. Den Besten, G.; van Eunen, K.; Groen, A.K.; Venema, K.; Reijngoud, D.J.; Bakker, B.M. The role of short-chain fatty acids in the interplay between diet, gut microbiota, and host energy metabolism. J. Lipid Res. 2013, 54, 2325-2340. [CrossRef]

139. Dumas, M.E.; Barton, R.H.; Toye, A.; Cloarec, O.; Blancher, C.; Rothwell, A.; Fearnside, J.; Tatoud, R.; Blanc, V.; Lindon, J.C.; et al Metabolic profiling reveals a contribution of gut microbiota to fatty liver phenotype in insulin-resistant mice. Proc. Natl. Acad. Sci. USA 2006, 103, 12511-12516. [CrossRef]

140. Ley, R.E.; Turnbaugh, P.J.; Klein, S.; Gordon, J.I. Microbial ecology: Human gut microbes associated with obesity. Nature 2006, 444, 1022-1023. [CrossRef]

141. Ley, R.E.; Backhed, F.; Turnbaugh, P.; Lozupone, C.A.; Knight, R.D.; Gordon, J.I. Obesity alters gut microbial ecology. Proc. Natl. Acad. Sci. USA 2005, 102, 11070-11075. [CrossRef]

142. Frank, D.N.; St Amand, A.L.; Feldman, R.A.; Boedeker, E.C.; Harpaz, N.; Pace, N.R. Molecular-phylogenetic characterization of microbial community imbalances in human inflammatory bowel diseases. Proc. Natl. Acad. Sci. USA 2007, 104, 13780-13785. [CrossRef]

143. Eckburg, P.B.; Bik, E.M.; Bernstein, C.N.; Purdom, E.; Dethlefsen, L.; Sargent, M.; Gill, S.R.; Nelson, K.E.; Relman, D.A. Diversity of the human intestinal microbial flora. Science 2005, 308, 1635-1638. [CrossRef]

144. Turnbaugh, P.J.; Backhed, F.; Fulton, L.; Gordon, J.I. Diet-induced obesity is linked to marked but reversible alterations in the mouse distal gut microbiome. Cell Host Microbe 2008, 3, 213-223. [CrossRef]

145. Bordeleau, M.; Fernandez de Cossio, L.; Chakravarty, M.M.; Tremblay, M.E. From Maternal Diet to Neurodevelopmental Disorders: A Story of Neuroinflammation. Front. Cell Neurosci. 2020, 14, 612705. [CrossRef]

146. Montalvo-Martinez, L.; Maldonado-Ruiz, R.; Cardenas-Tueme, M.; Resendez-Perez, D.; Camacho, A. Maternal Overnutrition Programs Central Inflammation and Addiction-Like Behavior in Offspring. Biomed. Res. Int. 2018, 2018, 8061389. [CrossRef]

147. Bolton, J.L.; Bilbo, S.D. Developmental programming of brain and behavior by perinatal diet: Focus on inflammatory mechanisms. Dialogues Clin. Neurosci. 2014, 16, 307-320. [PubMed]

148. Castanon, N.; Luheshi, G.; Laye, S. Role of neuroinflammation in the emotional and cognitive alterations displayed by animal models of obesity. Front. Neurosci. 2015, 9, 229. [CrossRef]

149. Ludwig, D.S.; Willett, W.C.; Volek, J.S.; Neuhouser, M.L. Dietary fat: From foe to friend? Science 2018, 362, 764-770. [CrossRef]

150. Moore, B.F.; Harrall, K.K.; Sauder, K.A.; Glueck, D.H.; Dabelea, D. Neonatal Adiposity and Childhood Obesity. Pediatrics 2020, 146, e20200737. [CrossRef] [PubMed]

151. Castillo-Ruiz, A.; Mosley, M.; George, A.J.; Mussaji, L.F.; Fullerton, E.F.; Ruszkowski, E.M.; Jacobs, A.J.; Gewirtz, A.T.; Chassaing, B.; Forger, N.G. The microbiota influences cell death and microglial colonization in the perinatal mouse brain. Brain Behav. Immun. 2018, 67, 218-229. [CrossRef]

152. Thion, M.S.; Ginhoux, F.; Garel, S. Microglia and early brain development: An intimate journey. Science 2018, 362, 185-189. [CrossRef]

153. Yilmaz, B.; Li, H. Gut Microbiota and Iron: The Crucial Actors in Health and Disease. Pharmaceuticals 2018, 11, 98. [CrossRef]

154. Deschemin, J.C.; Noordine, M.L.; Remot, A.; Willemetz, A.; Afif, C.; Canonne-Hergaux, F.; Langella, P.; Karim, Z.; Vaulont, S.; Thomas, M.; et al. The microbiota shifts the iron sensing of intestinal cells. FASEB J. 2016, 30, 252-261. [CrossRef] 
155. Hibberd, M.C.; Wu, M.; Rodionov, D.A.; Li, X.; Cheng, J.; Griffin, N.W.; Barratt, M.J.; Giannone, R.J.; Hettich, R.L.; Osterman, A.L.; et al. The effects of micronutrient deficiencies on bacterial species from the human gut microbiota. Sci. Transl. Med. 2017, 9. [CrossRef]

156. Sandstead, H.H.; Penland, J.G.; Alcock, N.W.; Dayal, H.H.; Chen, X.C.; Li, J.S.; Zhao, F.; Yang, J.J. Effects of repletion with zinc and other micronutrients on neuropsychologic performance and growth of Chinese children. Am. J. Clin. Nutr. 1998, 68, 470S-475S. [CrossRef] [PubMed]

157. Penland, J.G.; Sandstead, H.H.; Alcock, N.W.; Dayal, H.H.; Chen, X.C.; Li, J.S.; Zhao, F.; Yang, J.J. A preliminary report: Effects of zinc and micronutrient repletion on growth and neuropsychological function of urban Chinese children. J. Am. Coll. Nutr. 1997, 16, 268-272. [CrossRef]

158. Tamura, T.; Goldenberg, R.L.; Ramey, S.L.; Nelson, K.G.; Chapman, V.R. Effect of zinc supplementation of pregnant women on the mental and psychomotor development of their children at 5 y of age. Am. J. Clin. Nutr. 2003, 77, 1512-1516. [CrossRef] [PubMed]

159. Friel, J.K.; Andrews, W.L.; Matthew, J.D.; Long, D.R.; Cornel, A.M.; Cox, M.; McKim, E.; Zerbe, G.O. Zinc supplementation in very-low-birth-weight infants. J. Pediatr. Gastroenterol. Nutr. 1993, 17, 97-104. [CrossRef]

160. Kirksey, A.; Wachs, T.D.; Yunis, F.; Srinath, U.; Rahmanifar, A.; McCabe, G.P.; Galal, O.M.; Harrison, G.G.; Jerome, N.W. Relation of maternal zinc nutriture to pregnancy outcome and infant development in an Egyptian village. Am. J. Clin. Nutr. 1994, 60, 782-792. [CrossRef] [PubMed]

161. Stoltzfus, R.J.; Kvalsvig, J.D.; Chwaya, H.M.; Montresor, A.; Albonico, M.; Tielsch, J.M.; Savioli, L.; Pollitt, E. Effects of iron supplementation and anthelmintic treatment on motor and language development of preschool children in Zanzibar: Double blind, placebo controlled study. BMJ 2001, 323, 1389-1393. [CrossRef]

162. Halterman, J.S.; Kaczorowski, J.M.; Aligne, C.A.; Auinger, P.; Szilagyi, P.G. Iron deficiency and cognitive achievement among school-aged children and adolescents in the United States. Pediatrics 2001, 107, 1381-1386. [CrossRef] [PubMed]

163. Idjradinata, P.; Pollitt, E. Reversal of developmental delays in iron-deficient anaemic infants treated with iron. Lancet 1993, 341, 1-4. [CrossRef]

164. Moffatt, M.E.; Longstaffe, S.; Besant, J.; Dureski, C. Prevention of iron deficiency and psychomotor decline in high-risk infants through use of iron-fortified infant formula: A randomized clinical trial. J. Pediatr. 1994, 125, 527-534. [CrossRef]

165. Levitsky, D.A.; Barnes, R.H. Nutritional and environmental interactions in the behavioral development of the rat: Long-term effects. Science 1972, 176, 68-71. [CrossRef]

166. Rosenberg, I.H.; Miller, J.W. Nutritional factors in physical and cognitive functions of elderly people. Am. J. Clin. Nutr. 1992, 55, 1237S-1243S. [CrossRef] [PubMed]

167. Lampkin, B.C.; Saunders, E.F. Nutritional vitamin B12 deficiency in an infant. J. Pediatr. 1969, 75, 1053-1055. [CrossRef]

168. Louwman, M.W.; van Dusseldorp, M.; van de Vijver, F.J.; Thomas, C.M.; Schneede, J.; Ueland, P.M.; Refsum, H.; van Staveren, W.A. Signs of impaired cognitive function in adolescents with marginal cobalamin status. Am. J. Clin. Nutr. 2000, 72, 762-769. [CrossRef] [PubMed]

169. Bisanz, J.E.; Enos, M.K.; PrayGod, G.; Seney, S.; Macklaim, J.M.; Chilton, S.; Willner, D.; Knight, R.; Fusch, C.; Fusch, G.; et al. Microbiota at Multiple Body Sites during Pregnancy in a Rural Tanzanian Population and Effects of Moringa-Supplemented Probiotic Yogurt. Appl. Environ. Microbiol. 2015, 81, 4965-4975. [CrossRef]

170. Depeint, F.; Bruce, W.R.; Shangari, N.; Mehta, R.; O’Brien, P.J. Mitochondrial function and toxicity: Role of B vitamins on the one-carbon transfer pathways. Chem. Biol. Interact. 2006, 163, 113-132. [CrossRef] [PubMed]

171. Atta, C.A.; Fiest, K.M.; Frolkis, A.D.; Jette, N.; Pringsheim, T.; St Germaine-Smith, C.; Rajapakse, T.; Kaplan, G.G.; Metcalfe, A. Global Birth Prevalence of Spina Bifida by Folic Acid Fortification Status: A Systematic Review and Meta-Analysis. Am. J. Public Health 2016, 106, e24-e34. [CrossRef]

172. LeBlanc, J.G.; Milani, C.; de Giori, G.S.; Sesma, F.; van Sinderen, D.; Ventura, M. Bacteria as vitamin suppliers to their host: A gut microbiota perspective. Curr. Opin. Biotechnol. 2013, 24, 160-168. [CrossRef] [PubMed]

173. Asrar, F.M.; O'Connor, D.L. Bacterially synthesized folate and supplemental folic acid are absorbed across the large intestine of piglets. J. Nutr. Biochem. 2005, 16, 587-593. [CrossRef]

174. Qiu, A.; Jansen, M.; Sakaris, A.; Min, S.H.; Chattopadhyay, S.; Tsai, E.; Sandoval, C.; Zhao, R.; Akabas, M.H.; Goldman, I.D. Identification of an intestinal folate transporter and the molecular basis for hereditary folate malabsorption. Cell 2006, 127, 917-928. [CrossRef]

175. Reynolds, E.H. The neurology of folic acid deficiency. Handb. Clin. Neurol. 2014, 120, 927-943. [CrossRef]

176. Koike, H.; Takahashi, M.; Ohyama, K.; Hashimoto, R.; Kawagashira, Y.; Iijima, M.; Katsuno, M.; Doi, H.; Tanaka, F.; Sobue, G. Clinicopathologic features of folate-deficiency neuropathy. Neurology 2015, 84, 1026-1033. [CrossRef]

177. Hogervorst, E.; Kassam, S.; Kridawati, A.; Soni, M.; Xin, X.; Shifu, X.; Rahardjo, T.B. Nutrition research in cognitive impairment/dementia, with a focus on soya and folate. Proc. Nutr. Soc. 2017, 76, 437-442. [CrossRef] [PubMed]

178. Bender, A.; Hagan, K.E.; Kingston, N. The association of folate and depression: A meta-analysis. J. Psychiatr. Res. 2017, 95, 9-18. [CrossRef]

179. Cao, B.; Wang, D.F.; Xu, M.Y.; Liu, Y.Q.; Yan, L.L.; Wang, J.Y.; Lu, Q.B. Lower folate levels in schizophrenia: A meta-analysis. Psychiatry Res. 2016, 245, 1-7. [CrossRef]

180. Park, S.; Kang, S.; Sol Kim, D. Folate and vitamin B-12 deficiencies additively impaired memory function and disturbed the gut microbiota in amyloid-beta infused rats. Int. J. Vitam. Nutr. Res. 2019, 1-13. [CrossRef] 
181. Grober, U.; Schmidt, J.; Kisters, K. Magnesium in Prevention and Therapy. Nutrients 2015, 7, 8199-8226. [CrossRef]

182. Yamanaka, R.; Shindo, Y.; Oka, K. Magnesium Is a Key Player in Neuronal Maturation and Neuropathology. Int. J. Mol. Sci. 2019, 20, 3439. [CrossRef] [PubMed]

183. Vink, R.; Nechifor, M. Magnesium in the Central Nervous System; University of Adelaide Press: Adelaide, Australia, $2011 ;$ p. 342.

184. Castilho, R.F.; Ward, M.W.; Nicholls, D.G. Oxidative stress, mitochondrial function, and acute glutamate excitotoxicity in cultured cerebellar granule cells. J. Neurochem. 1999, 72, 1394-1401. [CrossRef] [PubMed]

185. Kirkland, A.E.; Sarlo, G.L.; Holton, K.F. The Role of Magnesium in Neurological Disorders. Nutrients 2018, 10, 730. [CrossRef] [PubMed]

186. Abumaria, N.; Yin, B.; Zhang, L.; Li, X.Y.; Chen, T.; Descalzi, G.; Zhao, L.; Ahn, M.; Luo, L.; Ran, C.; et al. Effects of elevation of brain magnesium on fear conditioning, fear extinction, and synaptic plasticity in the infralimbic prefrontal cortex and lateral amygdala. J. Neurosci. 2011, 31, 14871-14881. [CrossRef] [PubMed]

187. Slutsky, I.; Sadeghpour, S.; Li, B.; Liu, G. Enhancement of synaptic plasticity through chronically reduced Ca ${ }^{2+}$ flux during uncorrelated activity. Neuron 2004, 44, 835-849. [CrossRef]

188. Pachikian, B.D.; Neyrinck, A.M.; Deldicque, L.; De Backer, F.C.; Catry, E.; Dewulf, E.M.; Sohet, F.M.; Bindels, L.B.; Everard, A.; Francaux, M.; et al. Changes in intestinal bifidobacteria levels are associated with the inflammatory response in magnesiumdeficient mice. J. Nutr. 2010, 140, 509-514. [CrossRef]

189. Effatpanah, M.; Rezaei, M.; Effatpanah, H.; Effatpanah, Z.; Varkaneh, H.K.; Mousavi, S.M.; Fatahi, S.; Rinaldi, G.; Hashemi, R. Magnesium status and attention deficit hyperactivity disorder (ADHD): A meta-analysis. Psychiatry Res. 2019, 274, 228-234. [CrossRef]

190. Takeda, A. Movement of zinc and its functional significance in the brain. Brain Res. Brain Res. Rev. 2000, 34, 137-148. [CrossRef]

191. Frederickson, C.J.; Suh, S.W.; Silva, D.; Frederickson, C.J.; Thompson, R.B. Importance of zinc in the central nervous system: The zinc-containing neuron. J. Nutr. 2000, 130, 1471S-1483S. [CrossRef]

192. Paoletti, P.; Vergnano, A.M.; Barbour, B.; Casado, M. Zinc at glutamatergic synapses. Neuroscience 2009, 158, 126-136. [CrossRef]

193. Sensi, S.L.; Paoletti, P.; Koh, J.Y.; Aizenman, E.; Bush, A.I.; Hershfinkel, M. The neurophysiology and pathology of brain zinc. J. Neurosci. 2011, 31, 16076-16085. [CrossRef]

194. Smart, T.G.; Hosie, A.M.; Miller, P.S. $\mathrm{Zn}^{2+}$ ions: Modulators of excitatory and inhibitory synaptic activity. Neuroscientist 2004, 10, 432-442. [CrossRef] [PubMed]

195. Besser, L.; Chorin, E.; Sekler, I.; Silverman, W.F.; Atkin, S.; Russell, J.T.; Hershfinkel, M. Synaptically released zinc triggers metabotropic signaling via a zinc-sensing receptor in the hippocampus. J. Neurosci. 2009, 29, 2890-2901. [CrossRef]

196. Choi, D.W.; Yokoyama, M.; Koh, J. Zinc neurotoxicity in cortical cell culture. Neuroscience 1988, 24, 67-79. [CrossRef]

197. Perry, D.K.; Smyth, M.J.; Stennicke, H.R.; Salvesen, G.S.; Duriez, P.; Poirier, G.G.; Hannun, Y.A. Zinc is a potent inhibitor of the apoptotic protease, caspase-3. A novel target for zinc in the inhibition of apoptosis. J. Biol. Chem. 1997, 272, 18530-18533. [CrossRef] [PubMed]

198. Cote, A.; Chiasson, M.; Peralta, M.R., 3rd; Lafortune, K.; Pellegrini, L.; Toth, K. Cell type-specific action of seizure-induced intracellular zinc accumulation in the rat hippocampus. J. Physiol. 2005, 566, 821-837. [CrossRef] [PubMed]

199. Plum, L.M.; Rink, L.; Haase, H. The essential toxin: Impact of zinc on human health. Int. J. Environ. Res. Public Health 2010, 7, 1342-1365. [CrossRef]

200. Szewczyk, B. Zinc homeostasis and neurodegenerative disorders. Front. Aging Neurosci. 2013, 5, 33. [CrossRef]

201. Reed, S.; Neuman, H.; Moscovich, S.; Glahn, R.P.; Koren, O.; Tako, E. Chronic Zinc Deficiency Alters Chick Gut Microbiota Composition and Function. Nutrients 2015, 7, 9768-9784. [CrossRef]

202. Sauer, A.K.; Grabrucker, A.M. Zinc Deficiency During Pregnancy Leads to Altered Microbiome and Elevated Inflammatory Markers in Mice. Front. Neurosci. 2019, 13, 1295. [CrossRef] [PubMed]

203. Salehi, B.; Mohammadbeigi, A.; Sheykholeslam, H.; Moshiri, E.; Dorreh, F. Omega-3 and Zinc supplementation as complementary therapies in children with attention-deficit/hyperactivity disorder. J. Res. Pharm. Pract. 2016, 5, 22-26. [CrossRef] [PubMed]

204. Garcion, E.; Wion-Barbot, N.; Montero-Menei, C.N.; Berger, F.; Wion, D. New clues about vitamin D functions in the nervous system. Trends Endocrinol. Metab. 2002, 13, 100-105. [CrossRef]

205. Brown, J.; Bianco, J.I.; McGrath, J.J.; Eyles, D.W. 1,25-dihydroxyvitamin D3 induces nerve growth factor, promotes neurite outgrowth and inhibits mitosis in embryonic rat hippocampal neurons. Neurosci. Lett. 2003, 343, 139-143. [CrossRef]

206. Burne, T.H.; McGrath, J.J.; Eyles, D.W.; Mackay-Sim, A. Behavioural characterization of vitamin D receptor knockout mice. Behav. Brain Res. 2005, 157, 299-308. [CrossRef]

207. Kalueff, A.V.; Lou, Y.R.; Laaksi, I.; Tuohimaa, P. Impaired motor performance in mice lacking neurosteroid vitamin D receptors. Brain Res. Bull. 2004, 64, 25-29. [CrossRef]

208. Zou, J.; Minasyan, A.; Keisala, T.; Zhang, Y.; Wang, J.H.; Lou, Y.R.; Kalueff, A.; Pyykko, I.; Tuohimaa, P. Progressive hearing loss in mice with a mutated vitamin D receptor gene. Audiol. Neurootol. 2008, 13, 219-230. [CrossRef]

209. Keisala, T.; Minasyan, A.; Lou, Y.R.; Zou, J.; Kalueff, A.V.; Pyykko, I.; Tuohimaa, P. Premature aging in vitamin D receptor mutant mice. J. Steroid Biochem. Mol. Biol. 2009, 115, 91-97. [CrossRef] [PubMed]

210. Shen, L.; Ji, H.F. Vitamin D deficiency is associated with increased risk of Alzheimer's disease and dementia: Evidence from meta-analysis. Nutr. J. 2015, 14, 76. [CrossRef] 
211. Ghareghani, M.; Reiter, R.J.; Zibara, K.; Farhadi, N. Latitude, Vitamin D, Melatonin, and Gut Microbiota Act in Concert to Initiate Multiple Sclerosis: A New Mechanistic Pathway. Front. Immunol. 2018, 9, 2484. [CrossRef] [PubMed]

212. Alfawaz, H.A.; Bhat, R.S.; Al-Ayadhi, L.; El-Ansary, A.K. Protective and restorative potency of Vitamin D on persistent biochemical autistic features induced in propionic acid-intoxicated rat pups. BMC Complement. Altern. Med. 2014, 14, 416. [CrossRef]

213. Mostafa, G.A.; Al-Ayadhi, L.Y. Reduced serum concentrations of 25-hydroxy vitamin D in children with autism: Relation to autoimmunity. J. Neuroinflamm. 2012, 9, 201. [CrossRef] [PubMed]

214. Abreu, M.T.; Kantorovich, V.; Vasiliauskas, E.A.; Gruntmanis, U.; Matuk, R.; Daigle, K.; Chen, S.; Zehnder, D.; Lin, Y.C.; Yang, H.; et al. Measurement of vitamin D levels in inflammatory bowel disease patients reveals a subset of Crohn's disease patients with elevated 1,25-dihydroxyvitamin D and low bone mineral density. Gut 2004, 53, 1129-1136. [CrossRef]

215. Dionne, S.; Calderon, M.R.; White, J.H.; Memari, B.; Elimrani, I.; Adelson, B.; Piccirillo, C.; Seidman, E.G. Differential effect of vitamin D on NOD2- and TLR-induced cytokines in Crohn's disease. Mucosal Immunol. 2014, 7, 1405-1415. [CrossRef]

216. Zhang, Y.G.; Wu, S.; Sun, J. Vitamin D, Vitamin D Receptor, and Tissue Barriers. Tissue Barriers 2013, 1, e23118. [CrossRef]

217. Fujita, H.; Sugimoto, K.; Inatomi, S.; Maeda, T.; Osanai, M.; Uchiyama, Y.; Yamamoto, Y.; Wada, T.; Kojima, T.; Yokozaki, H.; et al. Tight junction proteins claudin-2 and -12 are critical for vitamin D-dependent $\mathrm{Ca}^{2+}$ absorption between enterocytes. Mol. Biol. Cell 2008, 19, 1912-1921. [CrossRef]

218. Charoenngam, N.; Shirvani, A.; Kalajian, T.A.; Song, A.; Holick, M.F. The Effect of Various Doses of Oral Vitamin D3 Supplementation on Gut Microbiota in Healthy Adults: A Randomized, Double-blinded, Dose-response Study. Anticancer Res. 2020, 40, 551-556. [CrossRef]

219. Ly, N.P.; Litonjua, A.; Gold, D.R.; Celedon, J.C. Gut microbiota, probiotics, and vitamin D: Interrelated exposures influencing allergy, asthma, and obesity? J. Allergy Clin. Immunol. 2011, 127, 1087-1094, quiz 1095-1086. [CrossRef]

220. Crawford, M.A. The role of dietary fatty acids in biology: Their place in the evolution of the human brain. Nutr. Rev. 1992, 50, 3-11. [CrossRef] [PubMed]

221. Fontani, G.; Corradeschi, F.; Felici, A.; Alfatti, F.; Migliorini, S.; Lodi, L. Cognitive and physiological effects of Omega-3 polyunsaturated fatty acid supplementation in healthy subjects. Eur. J. Clin. Investig. 2005, 35, 691-699. [CrossRef]

222. Chalon, S. The role of fatty acids in the treatment of ADHD. Neuropharmacology 2009, 57, 636-639. [CrossRef] [PubMed]

223. Burdge, G. Alpha-linolenic acid metabolism in men and women: Nutritional and biological implications. Curr. Opin. Clin. Nutr. Metab. Care 2004, 7, 137-144. [CrossRef] [PubMed]

224. German, J.B.; Dillard, C.J. Saturated fats: What dietary intake? Am. J. Clin. Nutr. 2004, 80, 550-559. [CrossRef]

225. Lopez-Vicente, M.; Ribas Fito, N.; Vilor-Tejedor, N.; Garcia-Esteban, R.; Fernandez-Barres, S.; Dadvand, P.; Murcia, M.; Rebagliato, M.; Ibarluzea, J.; Lertxundi, A.; et al. Prenatal Omega-6:Omega-3 Ratio and Attention Deficit and Hyperactivity Disorder Symptoms. J. Pediatr. 2019, 209, 204-211.e4. [CrossRef]

226. Burgess, J.R.; Stevens, L.; Zhang, W.; Peck, L. Long-chain polyunsaturated fatty acids in children with attention-deficit hyperactivity disorder. Am. J. Clin. Nutr. 2000, 71, 327S-330S. [CrossRef]

227. Strain, J.J.; Davidson, P.W.; Bonham, M.P.; Duffy, E.M.; Stokes-Riner, A.; Thurston, S.W.; Wallace, J.M.; Robson, P.J.; Shamlaye, C.F.; Georger, L.A.; et al. Associations of maternal long-chain polyunsaturated fatty acids, methyl mercury, and infant development in the Seychelles Child Development Nutrition Study. Neurotoxicology 2008, 29, 776-782. [CrossRef]

228. Sabel, K.G.; Strandvik, B.; Petzold, M.; Lundqvist-Persson, C. Motor, mental and behavioral developments in infancy are associated with fatty acid pattern in breast milk and plasma of premature infants. Prostaglandins Leukot. Essent. Fatty Acids 2012, 86, 183-188. [CrossRef]

229. Bernard, J.Y.; De Agostini, M.; Forhan, A.; de Lauzon-Guillain, B.; Charles, M.A.; Heude, B.; Group, E.M.-C.C.S. The dietary n6:n3 fatty acid ratio during pregnancy is inversely associated with child neurodevelopment in the EDEN mother-child cohort. J. Nutr. 2013, 143, 1481-1488. [CrossRef]

230. Kim, H.; Kim, H.; Lee, E.; Kim, Y.; Ha, E.H.; Chang, N. Association between maternal intake of n-6 to n-3 fatty acid ratio during pregnancy and infant neurodevelopment at 6 months of age: Results of the MOCEH cohort study. Nutr. J. 2017, 16, 23. [CrossRef]

231. Miyamoto, J.; Igarashi, M.; Watanabe, K.; Karaki, S.I.; Mukouyama, H.; Kishino, S.; Li, X.; Ichimura, A.; Irie, J.; Sugimoto, Y.; et al Gut microbiota confers host resistance to obesity by metabolizing dietary polyunsaturated fatty acids. Nat. Commun. 2019, 10, 4007. [CrossRef]

232. Kishino, S.; Takeuchi, M.; Park, S.B.; Hirata, A.; Kitamura, N.; Kunisawa, J.; Kiyono, H.; Iwamoto, R.; Isobe, Y.; Arita, M.; et al. Polyunsaturated fatty acid saturation by gut lactic acid bacteria affecting host lipid composition. Proc. Natl. Acad. Sci. USA 2013, 110, 17808-17813. [CrossRef]

233. Kishino, S.; Ogawa, J.; Yokozeki, K.; Shimizu, S. Metabolic diversity in biohydrogenation of polyunsaturated fatty acids by lactic acid bacteria involving conjugated fatty acid production. Appl. Microbiol. Biotechnol. 2009, 84, 87-97. [CrossRef]

234. Kishino, S.; Park, S.B.; Takeuchi, M.; Yokozeki, K.; Shimizu, S.; Ogawa, J. Novel multi-component enzyme machinery in lactic acid bacteria catalyzing $\mathrm{C}=\mathrm{C}$ double bond migration useful for conjugated fatty acid synthesis. Biochem. Biophys. Res. Commun. 2011, 416, 188-193. [CrossRef]

235. Takeuchi, M.; Kishino, S.; Hirata, A.; Park, S.B.; Kitamura, N.; Ogawa, J. Characterization of the linoleic acid Delta9 hydratase catalyzing the first step of polyunsaturated fatty acid saturation metabolism in Lactobacillus plantarum AKU 1009a. J. Biosci. Bioeng. 2015, 119, 636-641. [CrossRef] [PubMed] 
236. Polan, C.E.; McNeill, J.J.; Tove, S.B. Biohydrogenation of Unsaturated Fatty Acids by Rumen Bacteria. J. Bacteriol. 1964, 88, 1056-1064. [CrossRef]

237. Miyamoto, J.; Mizukure, T.; Park, S.B.; Kishino, S.; Kimura, I.; Hirano, K.; Bergamo, P.; Rossi, M.; Suzuki, T.; Arita, M.; et al. A gut microbial metabolite of linoleic acid, 10-hydroxy-cis-12-octadecenoic acid, ameliorates intestinal epithelial barrier impairment partially via GPR40-MEK-ERK pathway. J. Biol. Chem. 2015, 290, 2902-2918. [CrossRef]

238. Nanthirudjanar, T.; Furumoto, H.; Zheng, J.; Kim, Y.I.; Goto, T.; Takahashi, N.; Kawada, T.; Park, S.B.; Hirata, A.; Kitamura, N.; et al. Gut Microbial Fatty Acid Metabolites Reduce Triacylglycerol Levels in Hepatocytes. Lipids 2015, 50, 1093-1102. [CrossRef]

239. Ohue-Kitano, R.; Yasuoka, Y.; Goto, T.; Kitamura, N.; Park, S.B.; Kishino, S.; Kimura, I.; Kasubuchi, M.; Takahashi, H.; Li, Y.; et al. alpha-Linolenic acid-derived metabolites from gut lactic acid bacteria induce differentiation of anti-inflammatory M2 macrophages through G protein-coupled receptor 40. FASEB J. 2018, 32, 304-318. [CrossRef]

240. Kaikiri, H.; Miyamoto, J.; Kawakami, T.; Park, S.B.; Kitamura, N.; Kishino, S.; Yonejima, Y.; Hisa, K.; Watanabe, J.; Ogita, T.; et al. Supplemental feeding of a gut microbial metabolite of linoleic acid, 10-hydroxy-cis-12-octadecenoic acid, alleviates spontaneous atopic dermatitis and modulates intestinal microbiota in NC/nga mice. Int. J. Food Sci. Nutr. 2017, 68, 941-951. [CrossRef] [PubMed]

241. Butel, M.J. Probiotics, gut microbiota and health. Med. Mal. Infect. 2014, 44, 1-8. [CrossRef] [PubMed]

242. Neufeld, K.M.; Kang, N.; Bienenstock, J.; Foster, J.A. Reduced anxiety-like behavior and central neurochemical change in germ-free mice. Neurogastroenterol. Motil. 2011, 23, 255-264.e119. [CrossRef]

243. Arentsen, T.; Khalid, R.; Qian, Y.; Diaz Heijtz, R. Sex-dependent alterations in motor and anxiety-like behavior of aged bacterial peptidoglycan sensing molecule 2 knockout mice. Brain Behav. Immun. 2018, 67, 345-354. [CrossRef] [PubMed]

244. Diaz Heijtz, R.; Wang, S.; Anuar, F.; Qian, Y.; Bjorkholm, B.; Samuelsson, A.; Hibberd, M.L.; Forssberg, H.; Pettersson, S. Normal gut microbiota modulates brain development and behavior. Proc. Natl. Acad. Sci. USA 2011, 108, 3047-3052. [CrossRef] [PubMed]

245. Wang, X.; Yang, J.; Zhang, H.; Yu, J.; Yao, Z. Oral probiotic administration during pregnancy prevents autism-related behaviors in offspring induced by maternal immune activation via anti-inflammation in mice. Autism Res. 2019, 12, 576-588. [CrossRef] [PubMed]

246. Lu, J.; Lu, L.; Yu, Y.; Baranowski, J.; Claud, E.C. Maternal administration of probiotics promotes brain development and protects offspring's brain from postnatal inflammatory insults in C57/BL6J mice. Sci. Rep. 2020, 10, 8178. [CrossRef] [PubMed]

247. Krishna, G.; Muralidhara. Oral supplements of inulin during gestation offsets rotenone-induced oxidative impairments and neurotoxicity in maternal and prenatal rat brain. Biomed. Pharmacother. 2018, 104, 751-762. [CrossRef] [PubMed]

248. Schmidt, K.; Cowen, P.J.; Harmer, C.J.; Tzortzis, G.; Errington, S.; Burnet, P.W. Prebiotic intake reduces the waking cortisol response and alters emotional bias in healthy volunteers. Psychopharmacology 2015, 232, 1793-1801. [CrossRef] 